\title{
LA-UR-20-21971
}

Approved for public release; distribution is unlimited.

Title:

Comparison of Residual Stress in SRS and LANL-welded 3013 Inner Containers

Author(s):

Stroud, Mary Ann

Berg, John M.

Kaufeld, Kimberly Ann

Intended for: Report

Issued: 
Disclaimer:

Los Alamos National Laboratory, an affirmative action/equal opportunity employer, is operated by Triad National Security, LLC for the National Nuclear Security Administration of U.S. Department of Energy under contract 89233218CNA000001. By approving this article, the publisher recognizes that the U.S. Government retains nonexclusive, royalty-free license to publish or reproduce the published form of this contribution, or to allow others to do so, for U.S. Government purposes. Los Alamos National Laboratory requests that the publisher identify this article as work performed under the auspices of the U.S. Department of Energy. Los Alamos National Laboratory strongly supports academic freedom and a researcher's right to publish; as an institution, however, the Laboratory does not endorse the viewpoint of a publication or guarantee its technical correctness. 


\section{Comparison of Residual Stress in SRS and LANL-welded 3013 Inner Containers}

\section{Table of Contents}

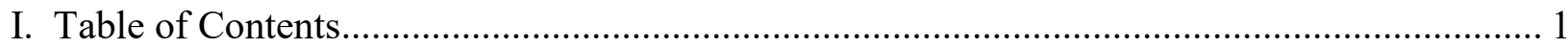

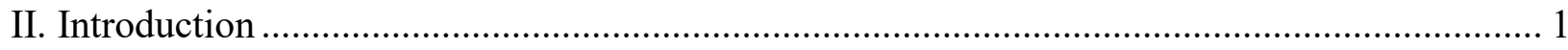

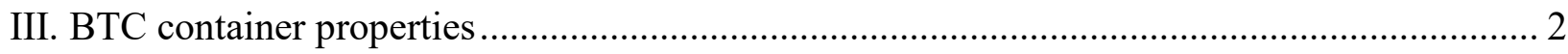

IV. Comparison of Stresses in SRS and LANL-welded BTCs................................................. 2

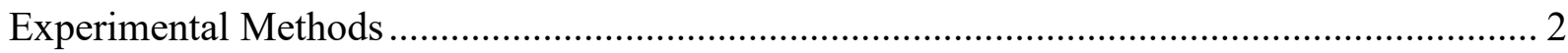

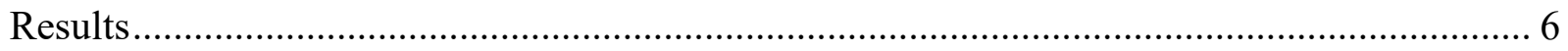

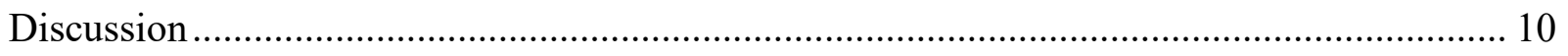

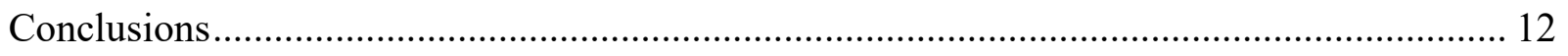

V. Effects of Cutting the Weld in LANL-Welded Containers.............................................. 12

Experimental Methods .................................................................................................... 12

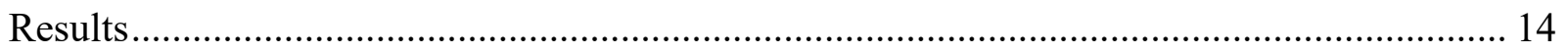

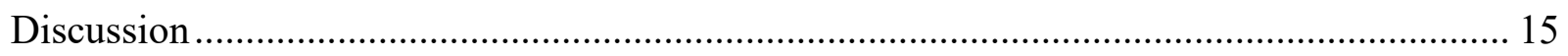

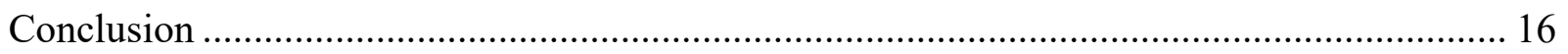

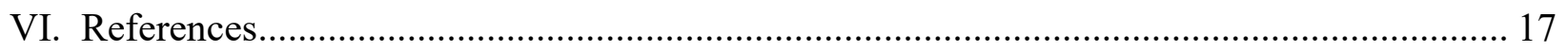

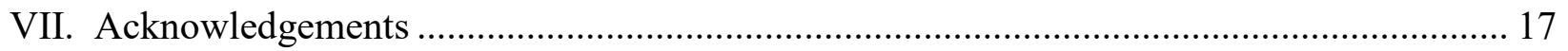

Appendix A: Material properties in 3013 inner BTC flow formed containers ......................... 18

Appendix B: Letter documenting BTC material properties.................................................. 18

Appendix C: Residual Stress and Uncertainty Measurements* ............................................. 19

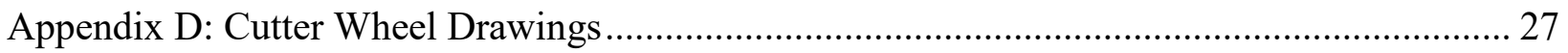

\section{Introduction}

The Department of Energy's 3013 Standard for packaging plutonium-bearing materials for storage up to fifty years specifies a minimum of two individually welded, nested containers, referred to as the 3013 outer and the 3013 inner. Stress corrosion cracking (SCC), which is dependent on the residual stress in the container, has been identified as a potential failure mechanism for 3013 inner containers which could result in the integrity of the Safety Class outer container being considered indeterminate. ${ }^{1}$ Previous measurements of residual stresses in 3013 bagless transfer can (BTC) inner containers used for packaging plutonium-bearing materials at Savannah River Site (SRS) and Hanford determined that the region of highest stress is in the closure weld region. ${ }^{2}$ Los Alamos National Laboratory (LANL) recently developed the capability to weld BTCs using the same technique and parameters used to weld the BTCs at SRS and Hanford. ${ }^{3}$ LANL-welded BTCs are being used for stress corrosion cracking experiments. 
This report compares residual stress measurements obtained by incremental hole drilling for BTC inner containers welded at SRS and LANL. Changes in residual stress due to bisecting the weld for partial lid removal is also discussed.

\section{BTC container properties}

The BTC inner containers which were made from 304L stainless steel (SS) with low sulfur content, were assumed to have the following elastic material properties: $\mathrm{E}=196 \mathrm{GPa}, v=0.285$. Precision flow forming, a cold metal forming process where a preform is extruded over a rotating mandrel to produce a rotationally symmetrical hollow component, was used to fabricate the BTC containers. This process significantly increased the yield strength of the material which allows high residual stresses to be present in the material and reduces the elongation measurement making BTCs more likely to crack (Appendix A). The parts used to assemble the BTCs welded at SRS and LANL were manufactured at the same location.

There are no fabrication welds in the container body, however there is a gas tungsten arc welding (GTAW) autogenous closure weld. ${ }^{4}$ The SRS-welded container with serial number H5117 was a prototype containers welded at SRS using the GTAW technique later implemented at Hanford. Unlike most of the inner containers in use for storage of nuclear material, the inner surface of this prototype containers was blasted with walnut shells to roughen the surface prior to machining and welding. In addition, there were two large weld defects in the lid of the SRSwelded container. The LANL-welded containers with serial number H8411 and H6291 were not blasted with walnut shells and had no weld defects.

\section{Comparison of Stresses in SRS and LANL-welded BTCs}

\section{Experimental Methods}

Prior to all hole drilling measurements, the non-welded bottom of the 3013 BTC was removed using a wire EDM as shown in Figure 1.

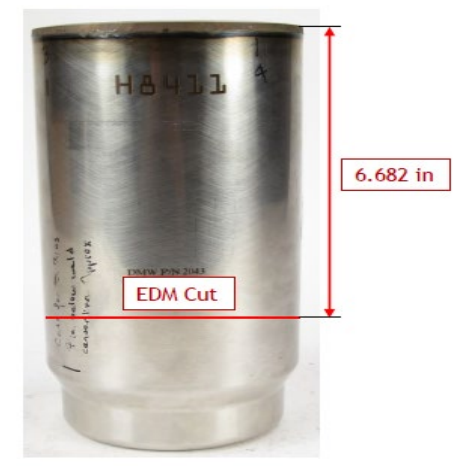

\section{Figure 1. Photograph of container showing diagram of cut to remove lower section.}

Incremental hole drilling was used to measure residual stresses in the containers. ${ }^{5}$ The incremental hole drilling method is a measurement technique for determining in-plane residual stress versus depth from the material surface. In the hole drilling method, a hole is incrementally extended into a body containing residual stress. The strain released with each increment in hole depth is measured using a strain gauge rosette placed around the hole. The measured strains versus hole depth data are used to calculate the residual stress that was initially in the part through an elastic inverse solution. 
Incremental hole drilling was used to measure residual stresses at four locations in the wall of the SRS-welded container (H5117) and three location in the wall of the LANL-welded container (H8411) near the closure weld. Each $1 \mathrm{~mm}$ diameter hole was drilled in $0.05 \mathrm{~mm}$ increments to a final depth of $1.0 \mathrm{~mm}$ except the LANL-welded HD12 which was drilled in $0.025 \mathrm{~mm}$ increments. The $0^{\circ}$ location was defined as the angular position of the stop location of the weld (Figure 2).

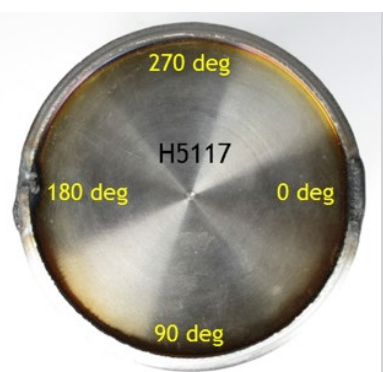

Figure 2. Photograph of lid f SRS-welded BTC container H5117 showing two large weld defects and angular position.

Information on the location of the holes for the SRS-welded container is shown in Table 1 and Figure 3.

\begin{tabular}{|l|l|l|l|l|}
\hline Location & $\begin{array}{l}\text { Distance of hole } \\
\text { center below the } \\
\text { weld toe }(\mathrm{mm})\end{array}$ & $\begin{array}{l}\text { Arc Length } \\
\text { from } 90^{\circ} \text { ref } \\
(\mathrm{mm})\end{array}$ & $\begin{array}{l}\text { Angular position } \\
\text { relative to the weld } \\
\text { stop location }\end{array}$ & Hole Start* \\
\hline SRS-HD9 & 2.6 & 19 & $109^{\circ}$ & OD \\
\hline SRS-HD10 & 1.0 & 19 & $71^{\circ}$ & OD \\
\hline SRS-HD11 & 2.5 & 6 & $96^{\circ}$ & ID \\
\hline SRS-HD12 & 2.6 & 6 & $84^{\circ}$ & ID \\
\hline
\end{tabular}

Table 1. Hole drilling measurement locations in SRS-welded container H5117. *OD -outer diameter, ID-inner diameter
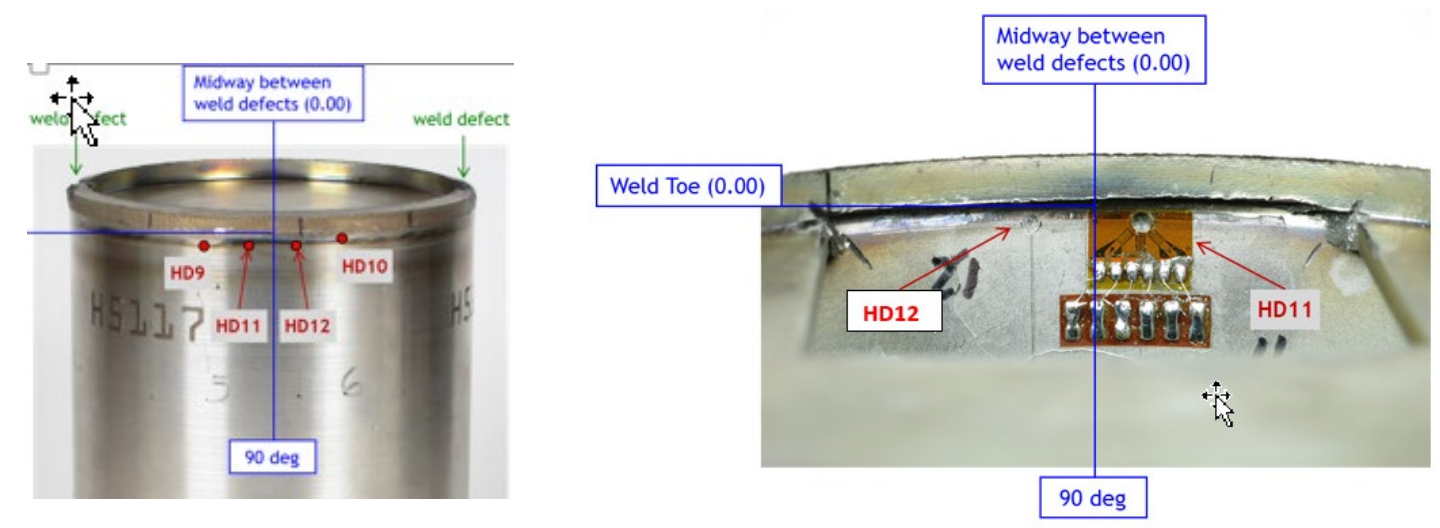

Figure 3. Photograph of the SRS-welded container showing the approximate hole drilling measurement location (left) and the actual locations SRS-HD11 and SRS-HD12 (right). Information on the location of the holes for the LANL-welded container are show in Table 2 and Figure 4. 


\begin{tabular}{|c|l|l|l|l|}
\hline Location & $\begin{array}{l}\text { Distance } \\
\text { below Weld } \\
(\mathrm{mm})\end{array}$ & $\begin{array}{l}\text { Arc Length } \\
\text { from 90 } \\
(\mathrm{mm})\end{array}$ & $\begin{array}{l}\text { Angular } \\
\text { Position }\end{array}$ & $\begin{array}{l}\text { Hole } \\
\text { Start }\end{array}$ \\
\hline LANL-HD9 & 1.7 & 18 & $72^{\circ}$ & OD \\
\hline LANL-HD11 & 2.5 & 7 & $97^{\circ}$ & ID \\
\hline LANL-HD12 & 2.0 & 6 & $84^{\circ}$ & ID \\
\hline
\end{tabular}

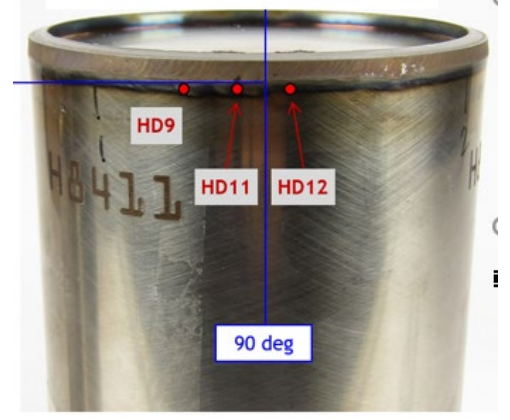

Table 2. Hole drilling measurement locations (left) and Figure 4. Photograph of approximate hole drilling measurement location on the LANL-welded container H8411 (right).

After measurements from the outer wall (HD 9 and where applicable HD10) but before measurements on the inner wall (HD11 and HD12), a window was removed from the welded lid of the containers in a two-step process using a wire EDM to enable hole drilling on the inner wall of the container close to the weld.
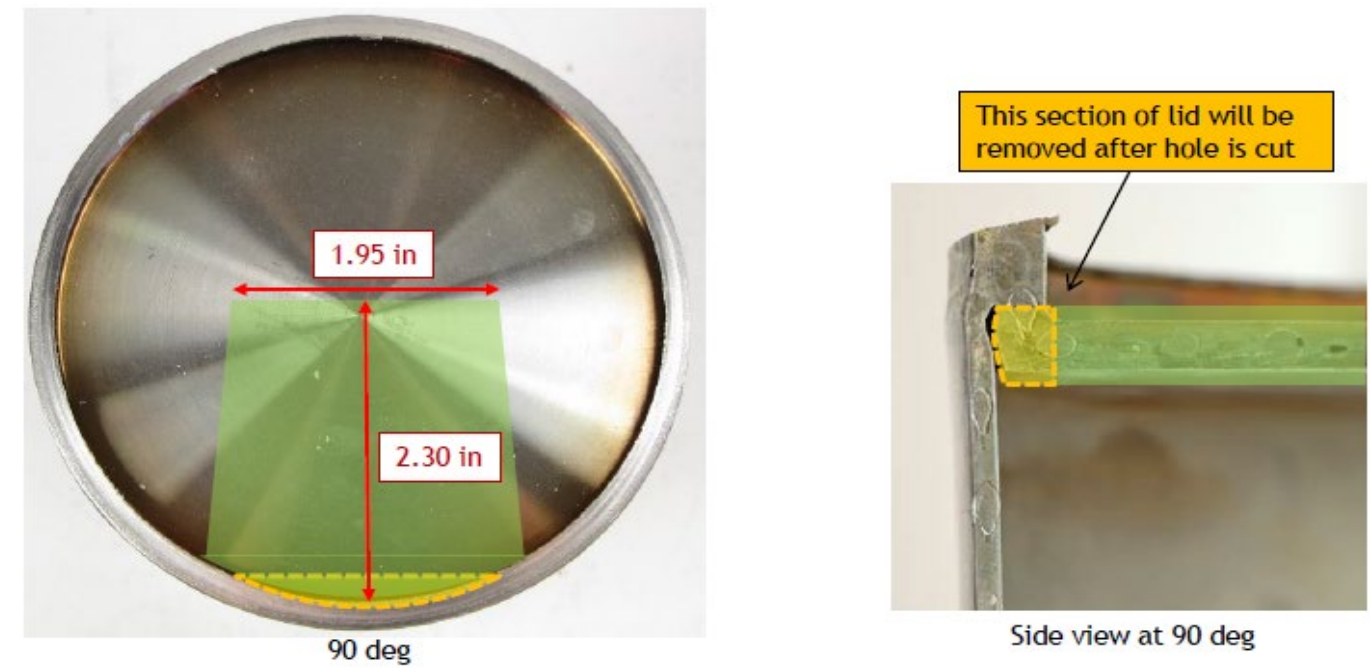

Side view at $90 \mathrm{deg}$

Figure 5. Photograph of Sectioning cuts- cut hole in lid (left) and cut to remove rest of lid lip to expose inner wall (right).

To measure the change in the residual stress distribution in the container due to those cuts in the lid, strain gages were installed on the outer diameter wall (OD) of the container near the locations of HD11 and HD12 for both the SRS and LANL-welded containers and on the inner diameter wall (ID) for the LANL-welded container only. (Figure 6). 

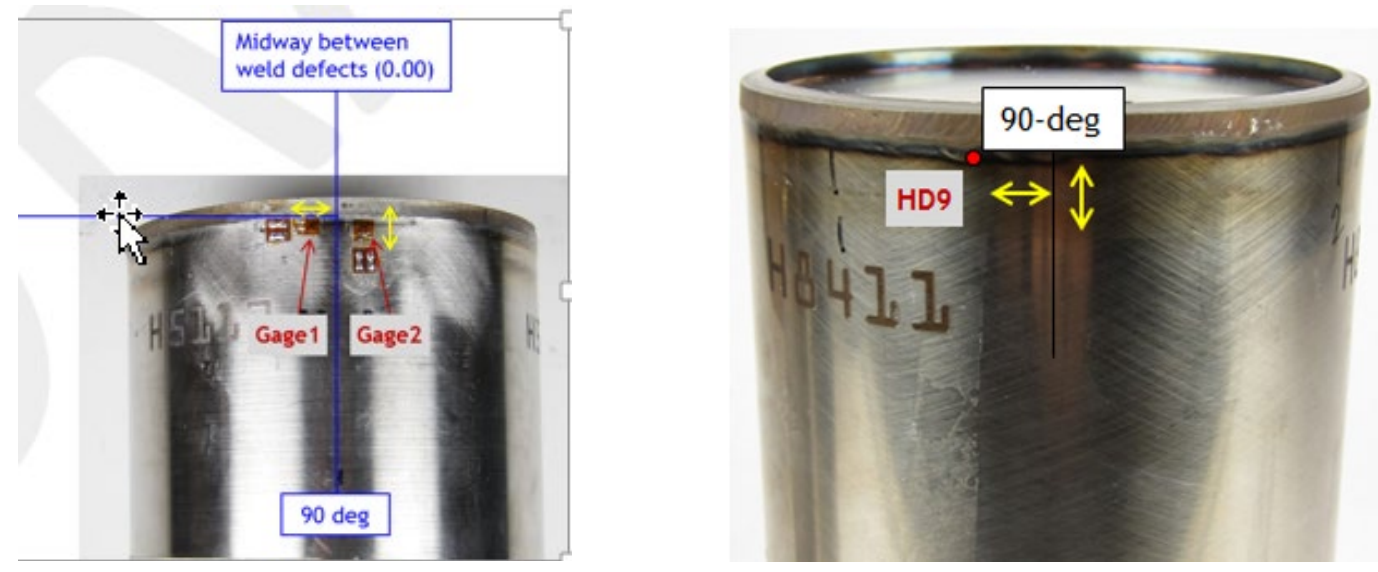

Figure 6. Photograph of strain gage placement and measurement direction for the sectioning cuts on SRS BTC H5117 (left) and the LANL BTC H8411 (right).

Table 3 summarizes the location of the "sectioning" strain gauges.

\begin{tabular}{|l|l|l|l|l|}
\hline Location & $\begin{array}{l}\text { Distance } \\
\text { below weld } \\
(\mathrm{mm})\end{array}$ & $\begin{array}{l}\text { Arc Length } \\
\text { from 90 } \\
(\mathrm{mm})\end{array}$ & $\begin{array}{l}\text { Angular } \\
\text { Position }\end{array}$ & Hole Start \\
\hline Gage 1 & 2.5 & 6.4 & $96^{\circ}$ & OD \\
\hline Gage 2 & 2.5 & 6.4 & $84^{\circ}$ & OD \\
\hline $\begin{array}{l}\text { Gage } 3 \\
\text { (LANL only) }\end{array}$ & 2.5 & 6.4 & $96^{\circ}$ & ID \\
\hline $\begin{array}{l}\text { Gage 4 } \\
\text { (LANL only) }\end{array}$ & 2.5 & 6.4 & $84^{\circ}$ & ID \\
\hline
\end{tabular}

\section{Table 3. Table of strain gauge measurement locations.}

Readings from the strain gages were recorded before and after the sectioning cut.

After the lid sectioning, HD11 and HD12 were drilled from the inner wall outward (Figure 7).
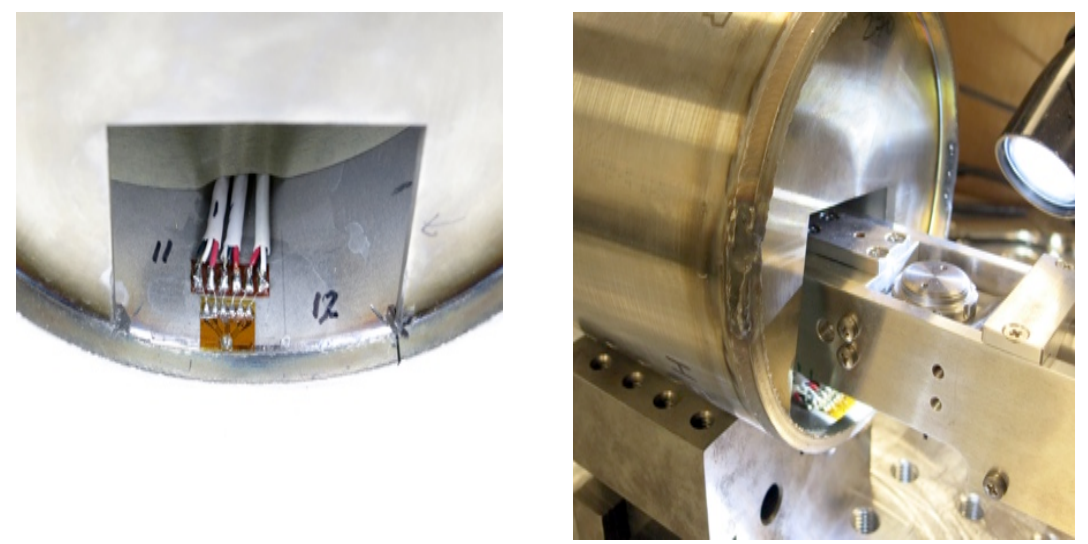

Figure 7. Photographs of SRS-welded inner container prior to drilling HD11 and HD12. 
Results

The measured strain values near the location of interest on the outer diameter (strain gage 1 and 2) recorded during the sectioning steps of the experiment on the SRS-welded container are shown in Table 4.

\begin{tabular}{|l|l|l|}
\cline { 2 - 3 } \multicolumn{1}{c|}{} & $\begin{array}{l}\text { Gage 1 (Hoop) } \\
{[\mu \varepsilon]}\end{array}$ & $\begin{array}{l}\text { Gage 2 (Axial) } \\
{[\mu \varepsilon]}\end{array}$ \\
\hline Strain change from cutting hole in lid & -1084 & -255 \\
\hline Strain change from removing lid lip & 394 & 173 \\
\hline Total strain change (final minus initial) & -690 & -82 \\
\hline
\end{tabular}

Table 4. Measurements of released strain due to removal of a section of the lid on the SRSwelded container. $($ Stress $=$ Strain $* \mathbf{E}=$ Strain $* 196 \mathrm{GPa})$

Assuming that the gages are oriented in the direction of the principal strains the released stress due to sectioning would constitute approximately -140 MPa in the hoop direction and -20 $\mathrm{MPa}$ in the axial direction. This means that the initial residual stress prior to removing a section of the lid would have been more tensile by approximately $140 \mathrm{MPa}$ in the hoop and $20 \mathrm{MPa}$ in the axial directions at the outer diameter of the container. These values are provided for reference. The reported measured residual stresses have not been corrected for the sectioning process.

The measured strain values near the location of interest on the outer diameter (strain gage 1 and 2 ) and the inner diameter ( 3 and 4 ) recorded during the sectioning steps of the experiment on the LANL-welded container are shown in Table 5.

\begin{tabular}{|l|c|c|c|c|}
\cline { 2 - 5 } \multicolumn{1}{c|}{} & $\begin{array}{c}\text { Gage 1 (OD } \\
\text { Hoop) }[\mu \varepsilon]\end{array}$ & $\begin{array}{c}\text { Gage 2 (OD } \\
\text { Axial) }[\mu \varepsilon]\end{array}$ & $\begin{array}{c}\text { Gage 3 (ID } \\
\text { Hoop) }[\mu \varepsilon]\end{array}$ & $\begin{array}{c}\text { Gage 4 (ID } \\
\text { Axial) }[\mu \varepsilon]\end{array}$ \\
\hline Strain change from removing non-weld end & -9 & -42 & N/A & N/A \\
\hline Strain change from cutting hole in lid & -1180 & -538 & -310 & 36 \\
\hline Strain change from removing lid lip & 181 & 67 & N/A & N/A \\
\hline \hline Total strain change & -1008 & -513 & N/A & N/A \\
\hline
\end{tabular}

Table 5. Measurements of released strain due to removal of a section of the lid on the LANL-welded container.

Assuming that the gages are oriented in the direction of the principal strains, for the LANLwelded container, the released stress due to sectioning on the outer diameter would constitute approximately $-200 \mathrm{MPa}$ in the hoop direction and $-100 \mathrm{MPa}$ in the axial direction.

This means that the initial residual stress prior to removing a section of the lid would have been more tensile by approximately $200 \mathrm{MPa}$ in the hoop and $100 \mathrm{MPa}$ in the axial direction at the outer diameter of the container. These values are provided for reference. The reported measured residual stresses have not been corrected for the sectioning process.

The measured strain values near the location of interest on the inner diameter (strain gage locations 3 and 4) recorded during the sectioning steps of the experiment are shown in 5. Assuming that the gages are oriented in the direction of the principal strains, the released stress due to cutting the hole in the lid would constitute approximately $60 \mathrm{MPa}$ in the hoop direction and $-7 \mathrm{MPa}$ in the axial direction. 
This means that the initial residual stress prior to removing a section of the lid would have been more tensile by approximately $60 \mathrm{MPa}$ in the hoop and more compressive by approximately $7 \mathrm{MPa}$ in the axial direction at the inner diameter of the container. It was not possible to leave the inner diameter strain gages on for the entire sectioning process due to the tight access requirements for the cutting tools. The inner diameter gages were only able to stay attached to the part for a portion the lid hole cutting operation. These values represent only a portion of the stress released due to the cumulative effect of the sectioning operations. A very rough approximation of the additional stress change can be made based on the additional strain changes observed on the outer wall after the inner gauges were removed. This rough estimate suggests the actual initial residual hoop stress on the inner wall prior to removing a section of the lid would have been $120 \mathrm{MPa}$ more tensile than the reported value. These values are provided for reference. The reported measured residual stresses have not been corrected for the sectioning process.

Hoop stress results of the HD9 - HD12 measurements for the SRS-welded container are shown in Figure 8.

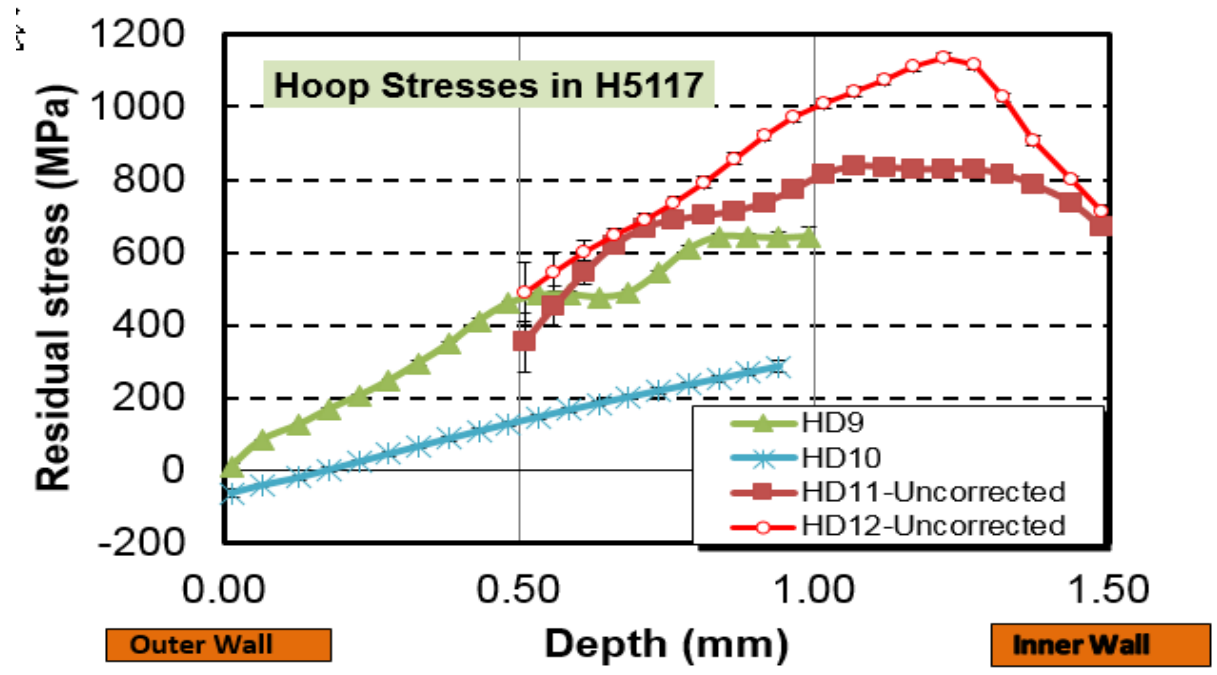

Figure 8. Line plot of hoop direction measured residual stresses in n SRS-welded H5117.

Hoop stresses of approximately $10 \mathrm{MPa}$ were present on the outer wall of the SRS-welded inner container at a position $2.5 \mathrm{~mm}$ below the weld toe (HD9). Stresses increased steadily with depth over the full depth range of the measurement. Similarly increasing but significantly smaller hoop stresses were observed $1 \mathrm{~mm}$ below the weld toe (HD10). Hoop stresses of approximately 690 MPa were measured on the inner wall near the weld (HD11 and HD12) and reached maximum values above $800 \mathrm{MPa} 0.3 \mathrm{~mm}$ below the inner surface before declining with depth. There was reasonable agreement in the measured stresses by outside-in (HD9) and inside-out drilling (HD11 and HD12) in wall regions where the measurements overlapped, though it should be born in mind that the inner-wall values are after cutting of the lid and have not been corrected for the effect of that process.

The residual axial stresses measured in the SRS-welded container using incremental hole drilling are shown in Figure 9. 


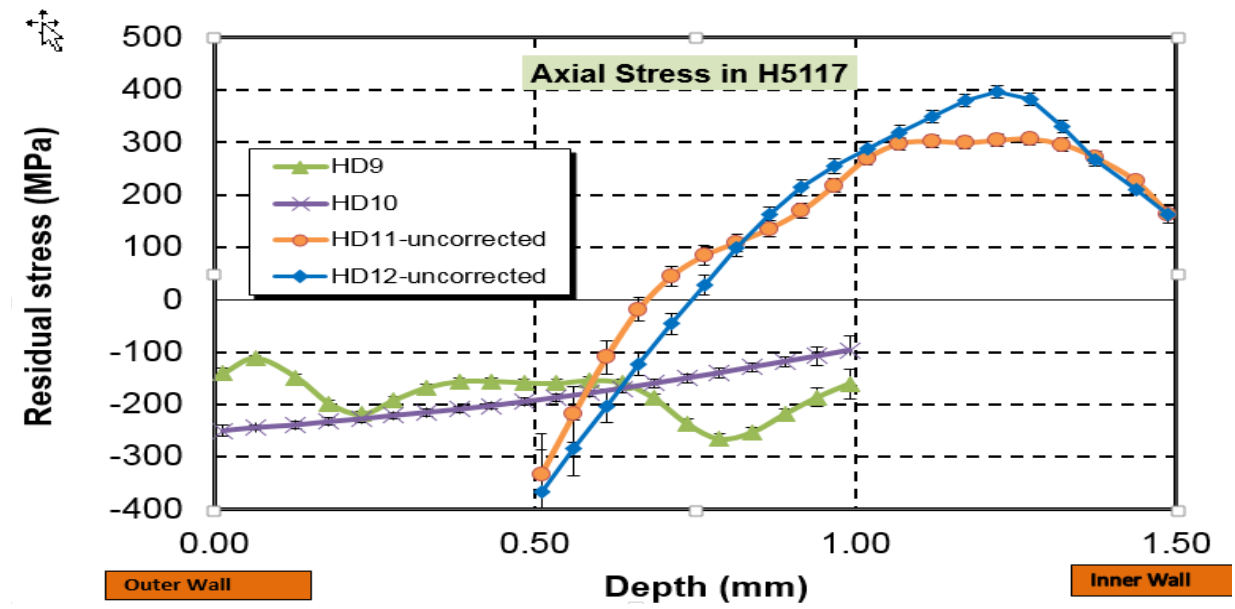

Figure 9. Line plot of axial direction measured residual stresses in n SRS-welded H5117.

Fairly constant compressive axial stresses between -100 and -300 MPa were found over the full 1 $\mathrm{mm}$ depth of the hole drilling measurements from the outer wall of container H5117 at $2.5 \mathrm{~mm}$ below the weld toe (HD9) and $1 \mathrm{~mm}$ below the weld toe (HD10). Measured values for HD9 andHD10 are detailed in Attachment 1, Table A8. Results were significantly different for the data obtained from the inner wall outward (HD11 and HD12). Axial stresses of approximately $160 \mathrm{MPa}$ were found at inner wall surface, rose above $300 \mathrm{MPa}$ from 0.2 to $0.5 \mathrm{~mm}$ below the surface, and then decreased to zero or compressive values at and beyond the midpoint of the wall. The agreement between inward and outward hole drilling in the overlap region is not as good as in other cases discussed above. Residual stresses and uncertainties for the axial and hoop stress for SRS-welded H5117 are detailed in Appendix C.

Hoop stress results of the HD9, HD11 and HD12 measurements for the LANL-welded container are shown in Figure 10.

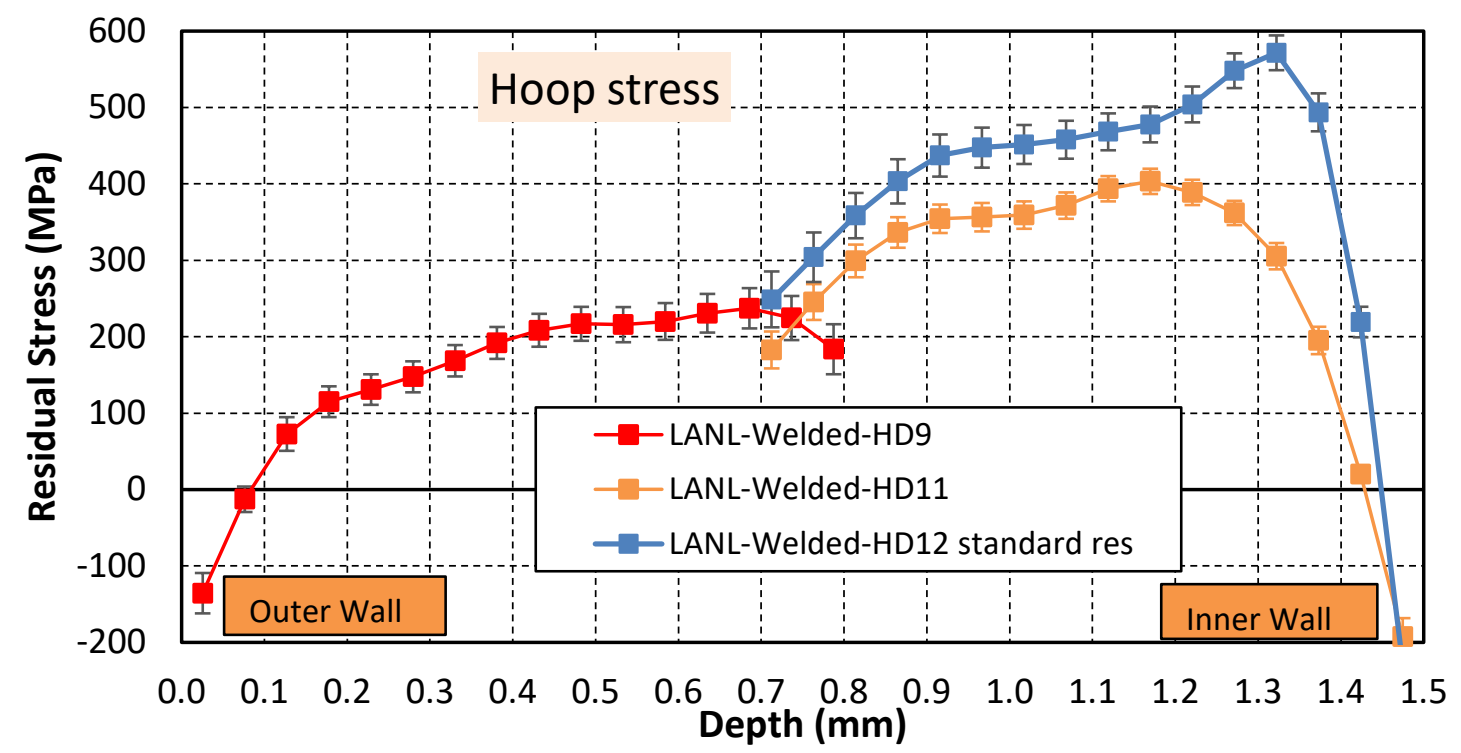

Figure 10. Line plot of hoop direction measured residual stresses in LANL-welded H8411. 
Compressive hoop stresses near the wall rose quickly in the first $0.1 \mathrm{~mm}$ from the outer wall. Stresses continues to rise at a slower rate reaching a maximum values of $400 \mathrm{MPa}(0.3 \mathrm{~mm}$ from the inner wall) and $570 \mathrm{MPa}$ ( $0.2 \mathrm{~mm}$ from the inner wall) before decreasing rapidly in the last $0.1 \mathrm{~mm}$ from the inside wall to become compressive again.

The residual axial stresses measured in the LANL-welded container using incremental hole drilling are shown in Figure 11.

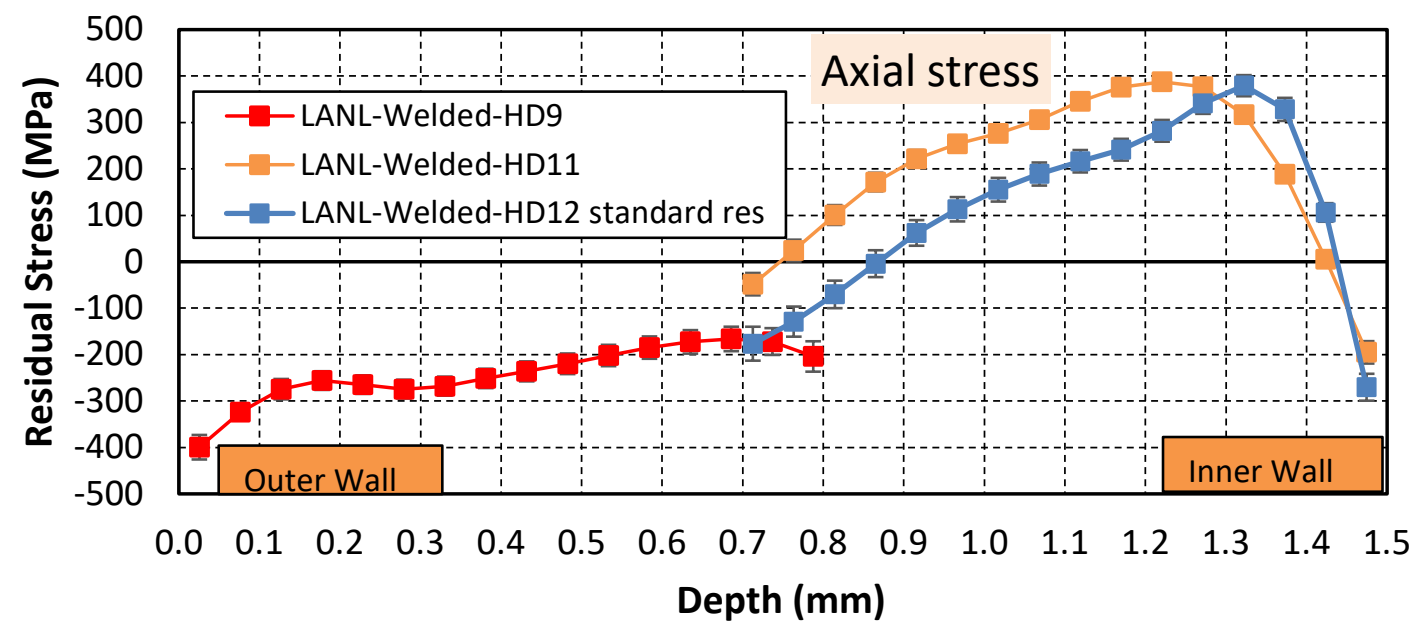

Figure 11. Line plot of axial direction measured residual stresses in LANL-welded H8411.

A similar trend was observed in the axial stresses. Compressive axial stresses near the wall rose quickly in the first $0.1 \mathrm{~mm}$ from the outer wall. Stresses continues to rise at a slower rate reaching a maximum values of $390 \mathrm{MPa}(0.3 \mathrm{~mm}$ from the inner wall) and $380 \mathrm{MPa}(0.2 \mathrm{~mm}$ from the inner wall) before decreasing rapidly in the last $0.1 \mathrm{~mm}$ from the inside wall to become compressive again. Residual stresses and uncertainties for the axial and hoop stress for LANLwelded H8411 are detailed in Appendix C. Graphs comparing the hoop and axial stress near the inner wall in the SRS and LANL-welded containers are shown in Figures 12 and Figures 13.

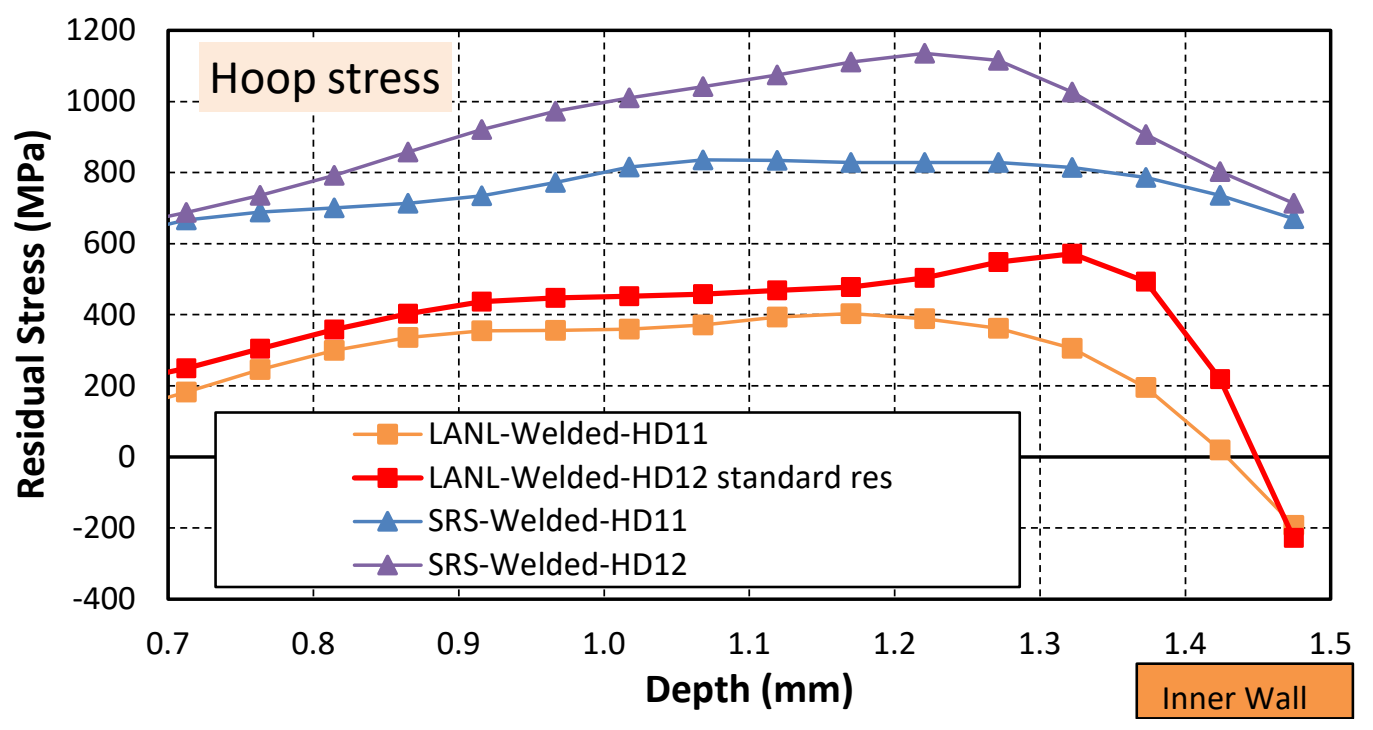


Figure 12. Comparison of hoop direction measured residual stresses in SRS-welded H5117 and LANL-welded H8411.

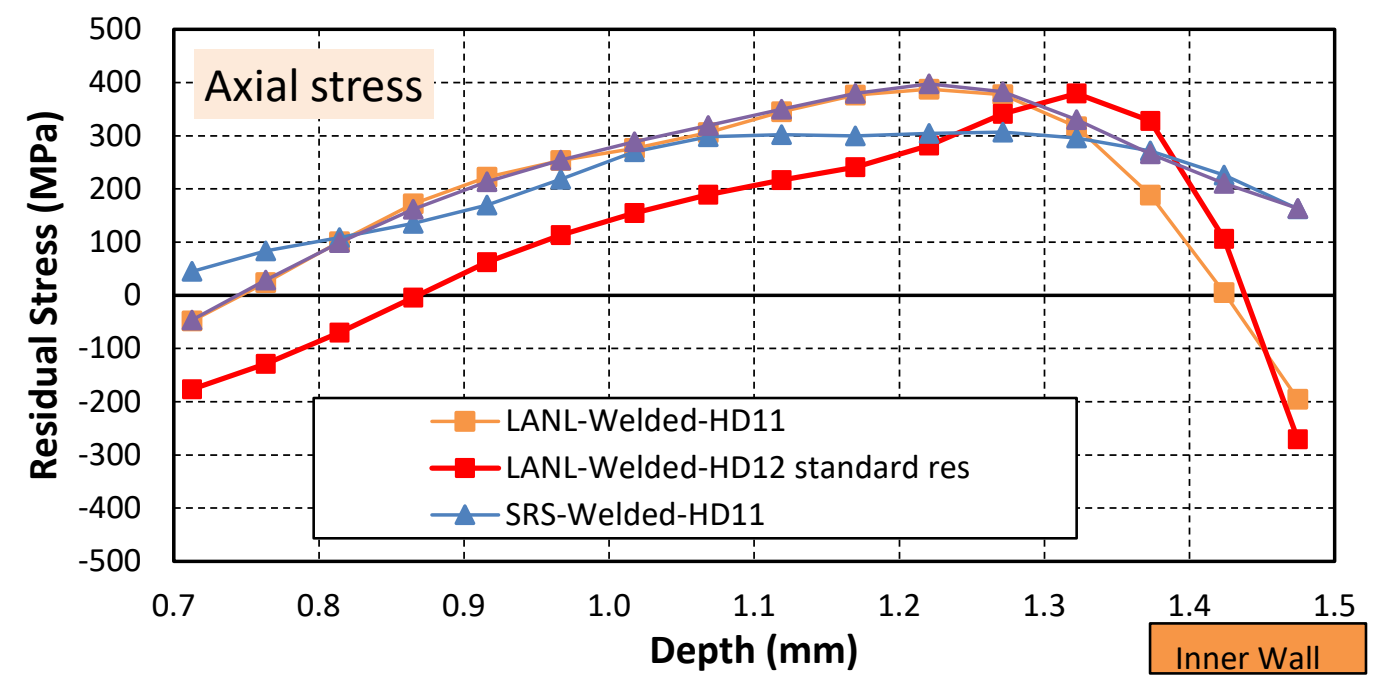

Figure 13. Comparison of axial direction measured residual stresses in SRS-welded H5117 and LANL-welded H8411.

Based on advice from Hill Engineering, a measurement was also taken $16 \mathrm{~mm}$ below the weld at a sufficient distance below the weld that residual stresses should not have been affected. Figure 14 compares the residual hoop stress from HD7 drilled $16 \mathrm{~mm}$ below the weld toe in LANLwelded H6291 with previously reported hole drilling results from two holes drilled 16mm below the weld toe in SRS-welded H5701. ${ }^{2}$

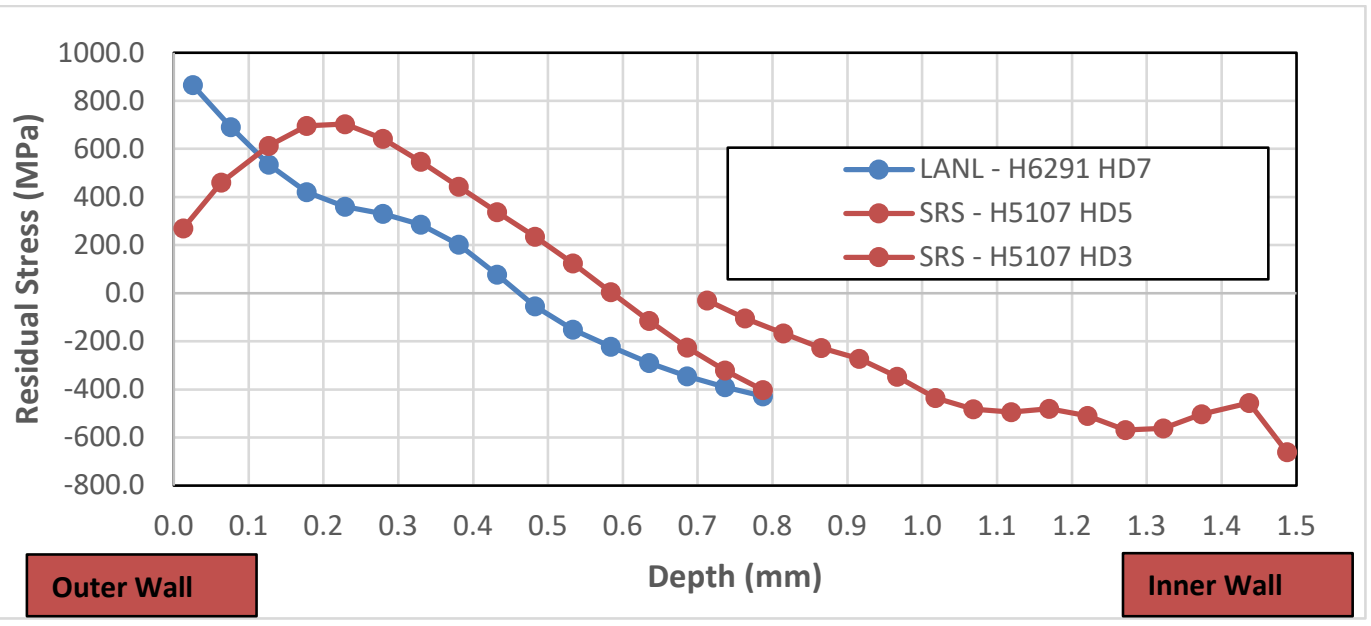

Figure 14. Hoop Stresses in LANL and SRS-welded container $16 \mathrm{~mm}$ below the weld toe.

Discussion

Hoop direction measured residual stresses were at least $200 \mathrm{MPa}$ more tensile in the SRS-welded container than in the LANL-welded container. These results are not corrected for changes in hoop stress due to sectioning which indicated a $50 \mathrm{MPa}$ difference in the magnitude of the change on the outer wall between the two containers. In contrast the axial direction measured residual stresses were similar in the two containers. These results are not corrected for the 
changes in axial stress due to sectioning which indicated a $40 \mathrm{MPa}$ difference in the magnitude of the change on the outer wall between the two containers.

A Wilcoxon Rank-Sum test, a nonparametric test similar to a t-test, was conducted to see if the hoop stresses are statistically different between the SRS and LANL-welded containers. The test checks to see if the distribution of the hoop stresses is the same across locations. To conduct this analysis, the stresses were grouped: results from the SRS-welded container were in one group and results from the LANL-welded were in another group. A boxplot is shown in Figure 15 displaying the variability of the measurements and the median hoop stress (line in the box).

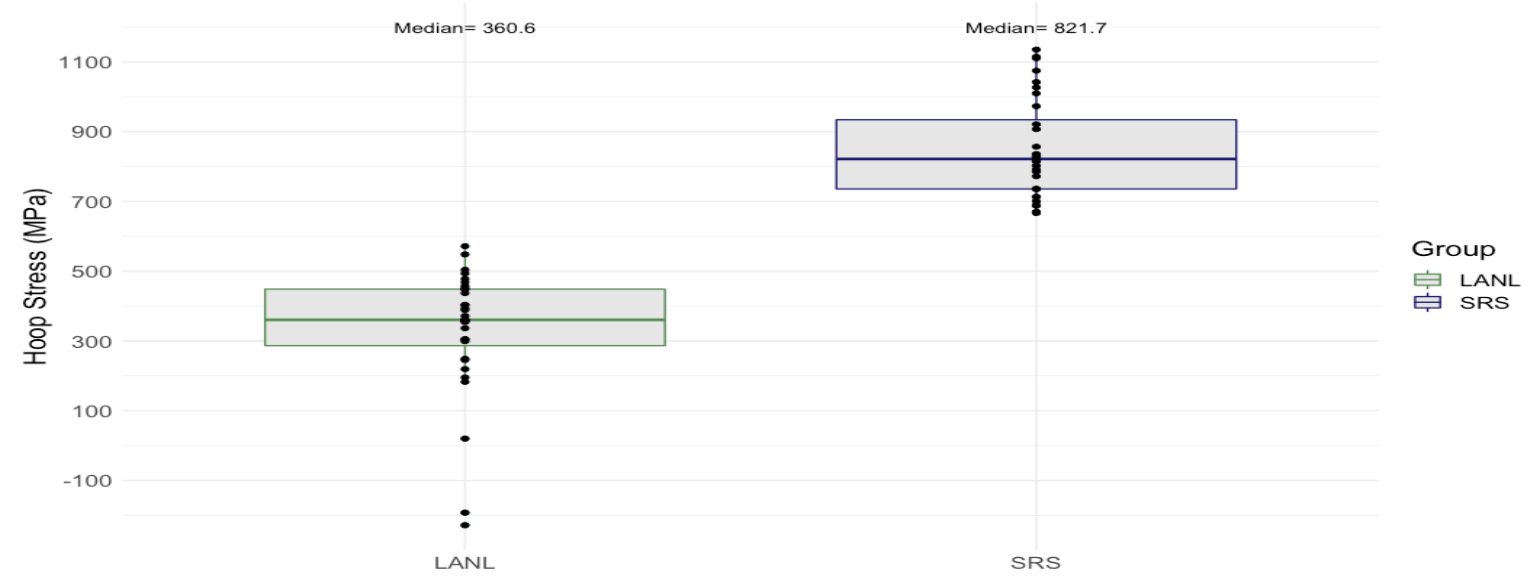

Figure 15: Boxplot of grouped hoop stresses in the LANL and SRS-welded containers.

The hoop stresses across groups were found to be significantly different at $p<0.001$. The SRS container hoop stress is higher than the LANL container hoop stress. Additionally, the mean of the two LANL curves and SRS hoop stress curves were compared to test to see if the mean stresses are different across locations. Again, the container stresses were also found to be significantly different at $p<0.001$. The hoop stress mean curve values of the SRS container is higher than the mean curve of the LANL container.

The hoop stress also varies per location, as can be seen in Figure 12. There are differences in the variation of the stress amongst containers at the same location. For example, the hoop stresses in the region of highest stress varied by $290 \mathrm{MPa}($ depth $=0.28 \mathrm{~mm})$ in the SRS container and 240 $\mathrm{MPa}($ depth $=0.33 \mathrm{~mm})$ in the LANL container at a given location. An additional test was conducted to check if the distributions of the curves are different at the same location. The LANL containers curve distributions are significantly different at $p<0.001$. Similarly, the SRS containers hoop stress curve distributions were also found to be significantly different at $\mathrm{p}<$ 0.001. The boxplot in Figure 16 shows the variability across the different hoop stress measurements. 


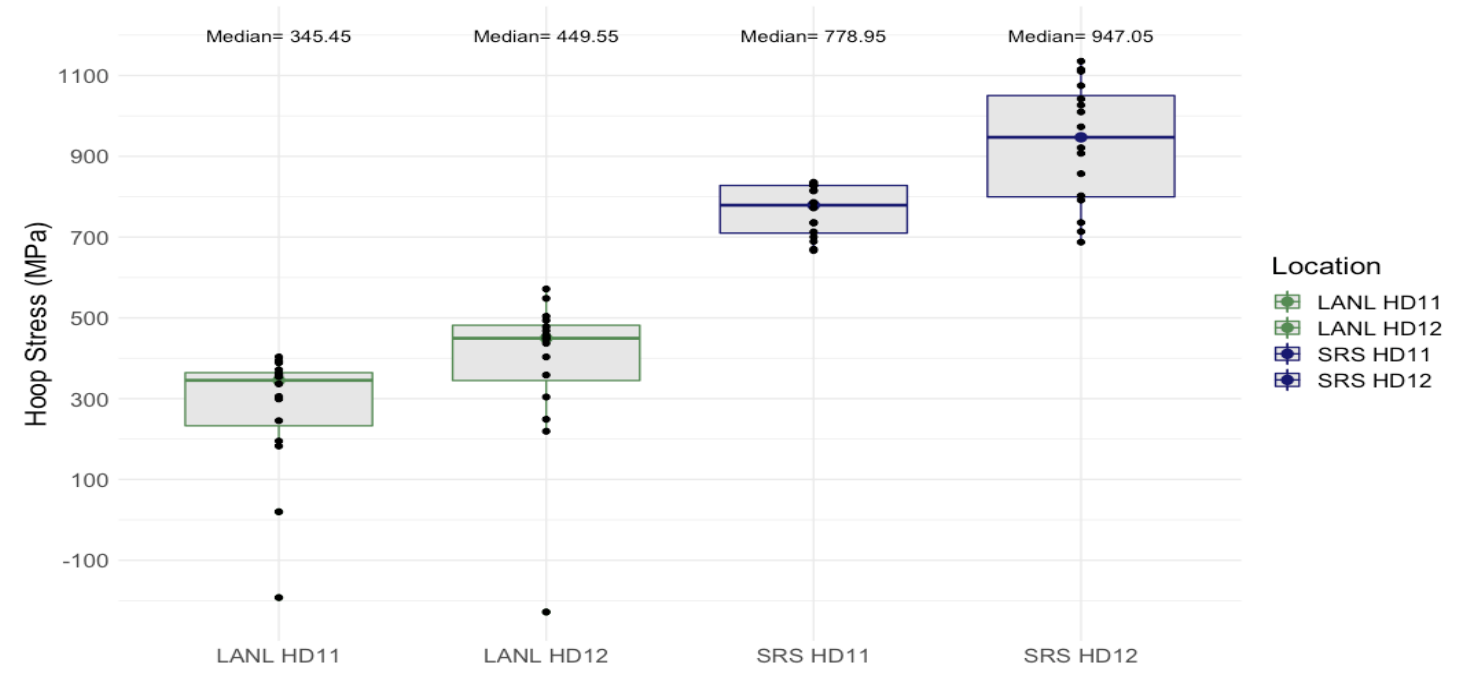

Figure 16: Boxplot of hoop stress measurements for LANL vs. SRS containers.

If the containers are looked at without respect to their location, we can test to see if there are difference among all of the curves. A Kruskal-Wallis test, a nonparametric test similar to ANOVA, was conducted to determine if the hoop stresses are different across all the curves. The result was the distribution of the hoop stresses measurements across the containers are significantly different $(\mathrm{p}<0.001)$. There was a notable difference in both the hoop and axial stresses, within $1 \mathrm{~mm}$ of the inner surface possibly due to differences in the inner surface finish. Near the inner wall surface stresses were compressive in the LANL-welded container but tensile in the walnut-blasted SRS-welded container H5117. In contrast, previously measured residual stresses in walnut-blasted SRS-welded container H5107, taken 16mm below the weld were compressive (Figure 14).

\section{Conclusions}

Hoop stresses measured from the inner wall near the weld were significantly higher in the SRSwelded container than in the LANL-welded container. The mean hoop stress at a given location was also significantly higher in the SRS container that the LANL container. Significant variation in the stresses between hole drilling locations in the same container were also observed. This may have been due, in part, to differences in the distance below the weld toe, as well as position relative to the tac welds or the weld start.

\section{Effects of Cutting the Weld in LANL-Welded Containers \\ Experimental Methods}

After welding, BTC inner containers are cut approximately $60 \%$ of the weld width up from the weld toe to remove the upper portion of the container. Over the course of the 3013 packaging effort, two separate cutter wheels were used for this lid removal. The original cutter (4140) used in FB-Line and in Hanford has a cut edge thickness of .018 - .023 inches. Some FB Line containers, cut using the 4140 cutter wheels, had a rough cut surface. Later, new cutter wheel (4340) was developed for FB Line. The width of the cut edge on the 4340 is reduced to .011 - .015inches. Drawings of the cutters are in Appendix D. In 2018 SRS re-established the 
capability to cut lids from BTC containers. Figure 17 shows a photograph of the SRS system as well as a container prior to cutting through the weld.
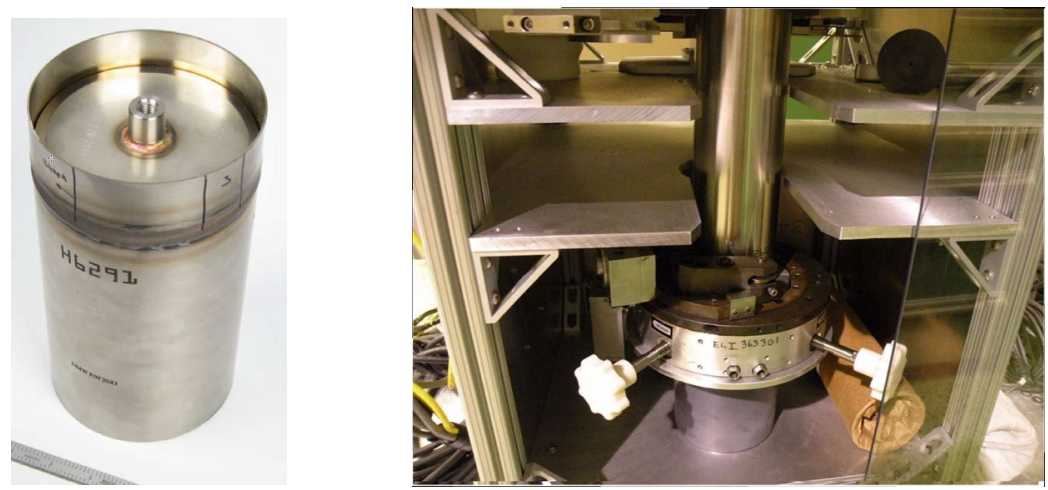

Figure 17. Photograph of H6291 prior to lid removal (left) and the SRS weld cutter (right).

To determine whether cutting the container through the weld has an effect on residual stresses near the weld, stresses on the outer surface approximately $2.5 \mathrm{~mm}$ below the weld toe were measured before and after lid removal using the hole drilling method. The hole drilling measurements were oriented to measure residual stress in the axial and hoop directions. A $2 \mathrm{~mm}$ diameter hole was drilled in increments of $0.05 \mathrm{~mm}$ to a final depth of $1 \mathrm{~mm}$. At each incremental hole depth, the strain change was monitored using a commercial Wheatstone Bridge instrument and recorded.

The holes (HD1, HD2 and HD3) were drilled at three locations near the weld on a LANL-welded container (H6291) with the weld still intact. Figure 14 illustrates the approximate measurement locations. The container was sent to SRS where a cut approximately $60 \%$ of the distance up from the weld toe was made to remove the upper portion of the container using a 4140 cutter. Three additional hole drilling measurements were made after the upper portion of the weld was removed. The hole drilling locations as well as the approximate location of the tac welds are shown in Figure 18.
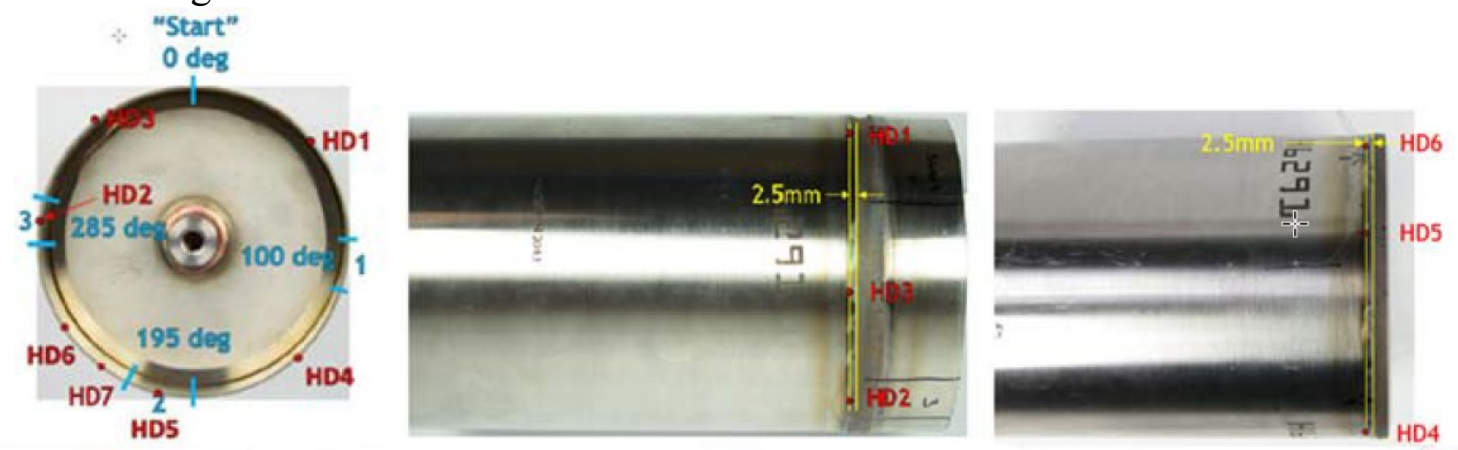

Figure 18. Diagrams showing the approximate hole drilling locations (HD\#) shown in red and the weld start and tac weld locations shown in light blue. 
Table 6 indicates the location of the holes drillings and whether they were measured pre or post cut.

\begin{tabular}{|l|l|l|l|l|l|l|}
\hline Hole Number & HD1 & HD2 & HD3 & HD4 & HD5 & HD6 \\
\hline Pre or Post Cut & Pre & Pre & Pre & Post & Post & Post \\
\hline $\begin{array}{l}\text { Angular Location relative } \\
\text { the weld start (degrees) }\end{array}$ & $50^{\circ}$ & $285^{\circ}$ & $322.5^{\circ}$ & $148^{\circ}$ & $195^{\circ}$ & $240^{\circ}$ \\
\hline
\end{tabular}

Table 6. Pre or Post cutting designation and location of hole drillings in H6291.

An additional hole, HD7, was drilled $16 \mathrm{~mm}$ below the weld toe in H6291 at approximately $217.5^{\circ}$. Results were shown in Figure 14.

Results

Line plots of the measured residual stress versus depth from the OUTER wall for all measurement locations on container H6291 are shown in Figure 19 and 20.

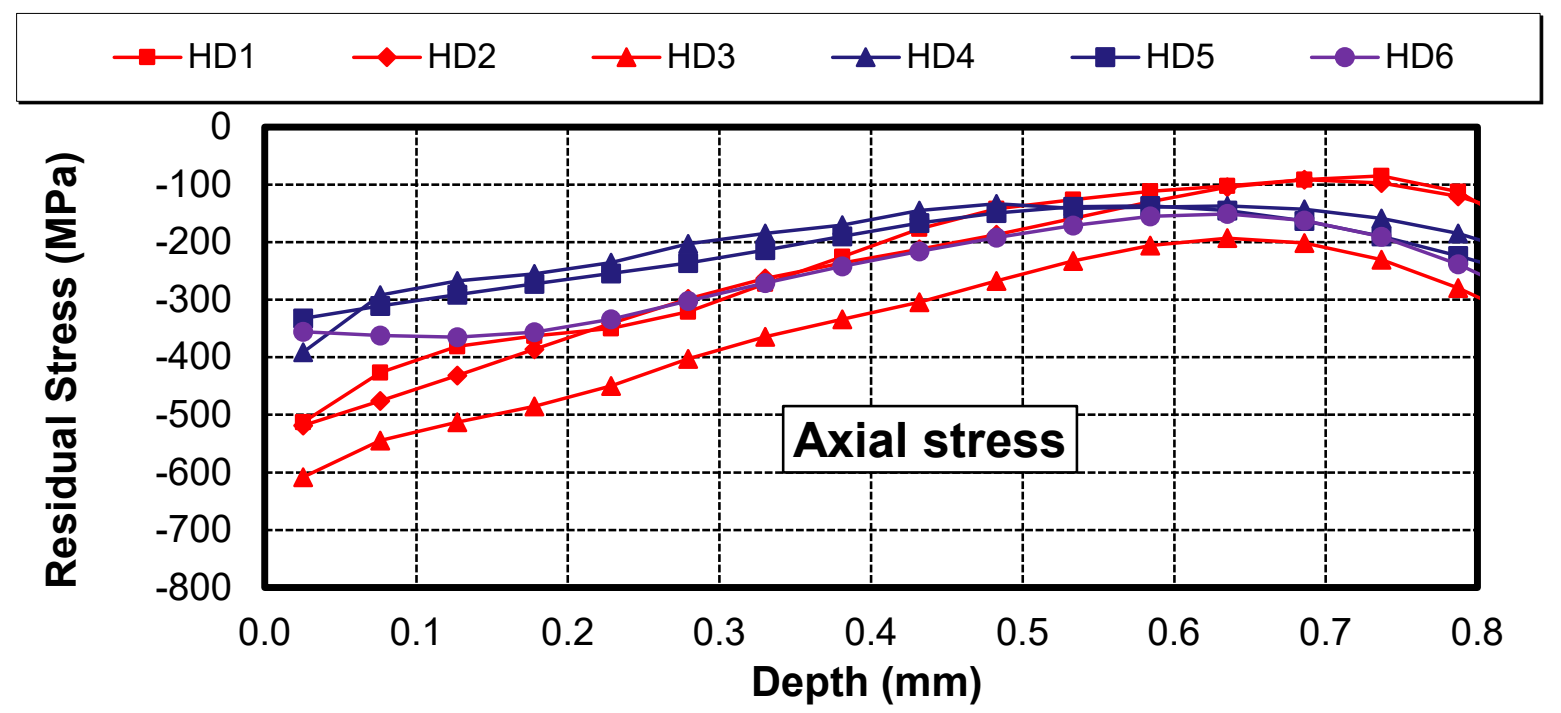

Figure 19. Line plots of measured axial residual stress versus depth for all hole drilling measurement locations before (red) and after (blue) lid removal.

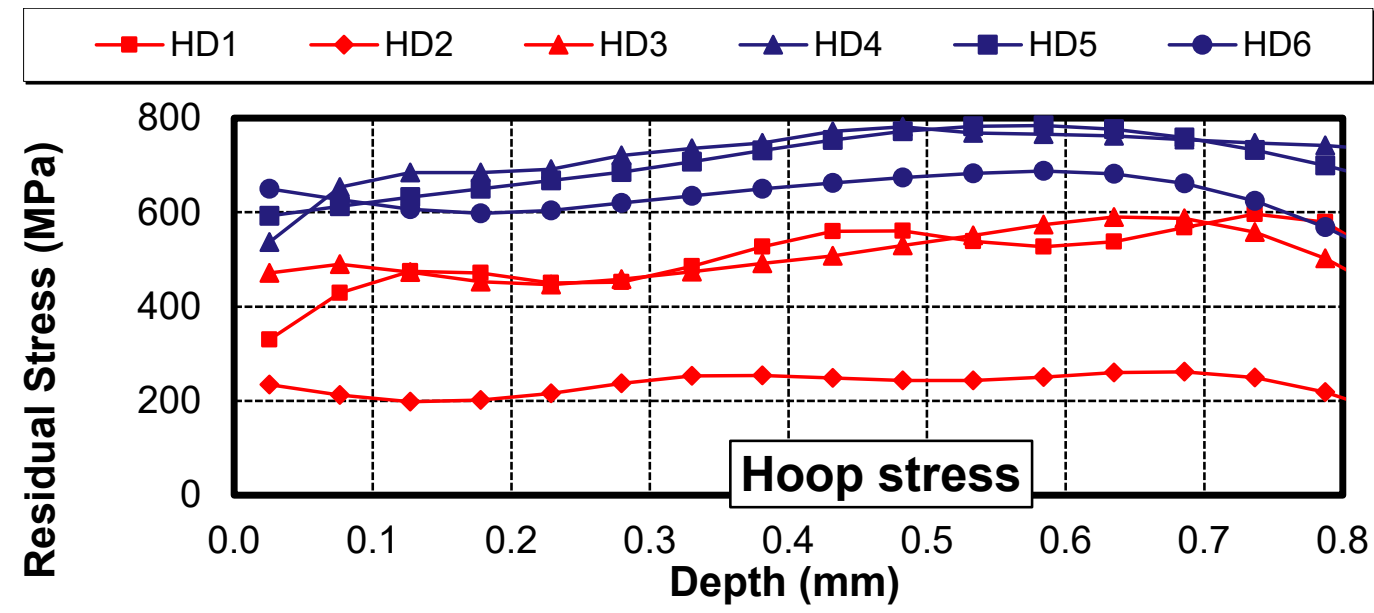

Figure 20. Line plots of measured hoop residual stress versus depth for all hole drilling measurement locations before (red) and after (blue) lid removal. 


\section{Discussion}

Axial stresses were less compressive near the wall after cutting, however this trend was not evident with increasing distance into the wall. In contrast, hoop stresses were more tensile in the container after cutting over the entire depth range measured. It is important to note that changes in stresses on the inner wall near the weld, the region of most importance in SSC, were not measured due to the difficulty accessing the inner wall near the weld.

The hoop stresses measured in LANL-welded can H6291 before and after cutting through the weld were compared to determine if the can stresses were significantly higher after cutting. The boxplot in Figure 21 shows the grouped pre vs post cut hoop stress measurements. When grouped, the post-cutting hoop stresses have a higher median (685 MPa) compared to the pre-cut (472 MPa) hoop stress.

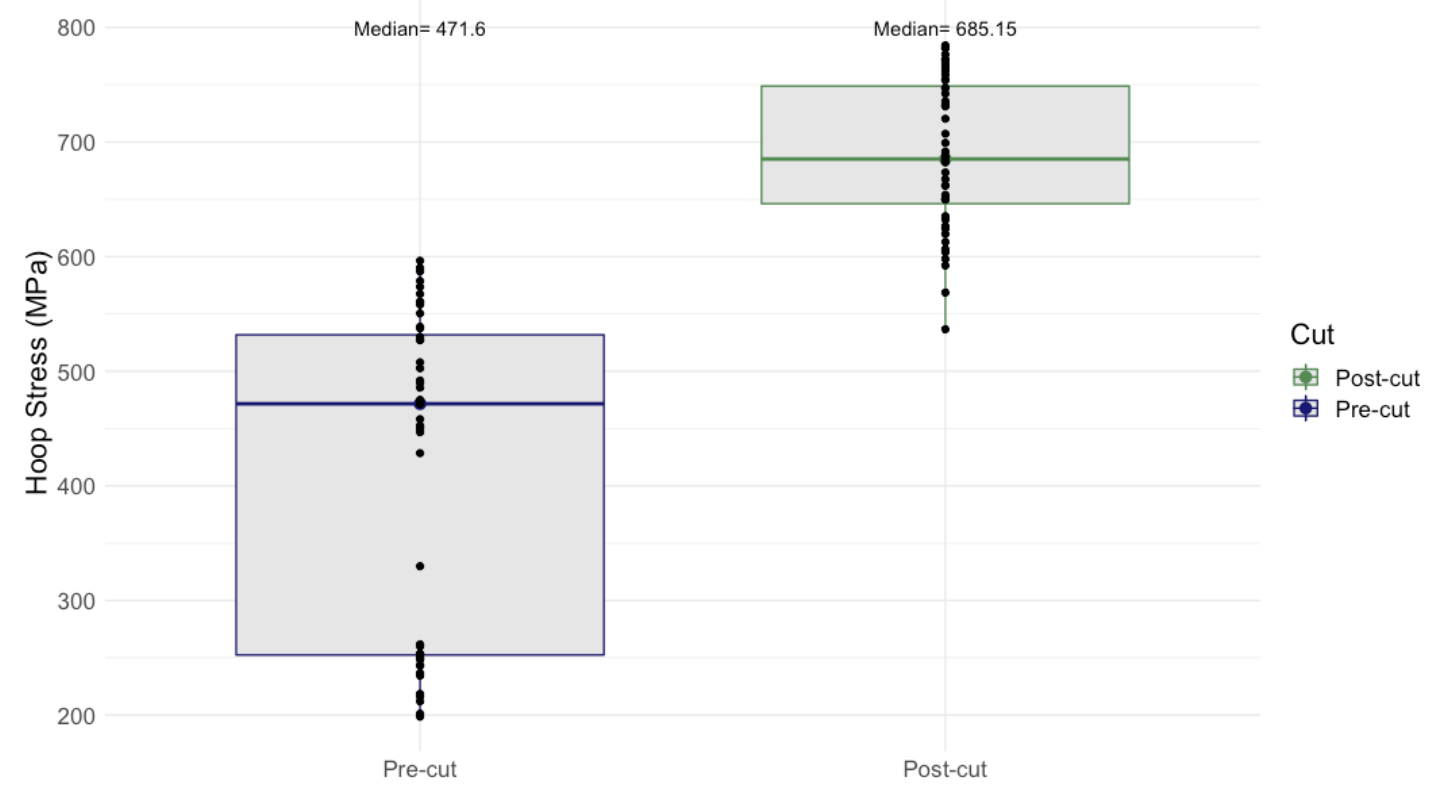

Figure 21. Grouped hoop stress measurements pre and post weld cut.

A Wilcoxon Rank-Sum test, a nonparametric test similar to a t-test, was conducted comparing the pre-cut hoop stresses to the post-cut stresses. To conduct this analysis the measurements from each location were grouped, i.e. post-cut measurements were from one group and pre-cut were from another group. The post-cut stresses were found to be significantly higher than the pre-cut stresses $(p<0.001)$. A boxplot displayed in Figure 22 shows the variability across the different hoop stress measurements even within the pre and post cuts. The boxplots in green at the pre-cut hoop stress values and the purple boxplot are the post-cut hoop stress values. The post-cut median and mean values are all higher than the pre-cuts but there was a lot of variability within a group. 


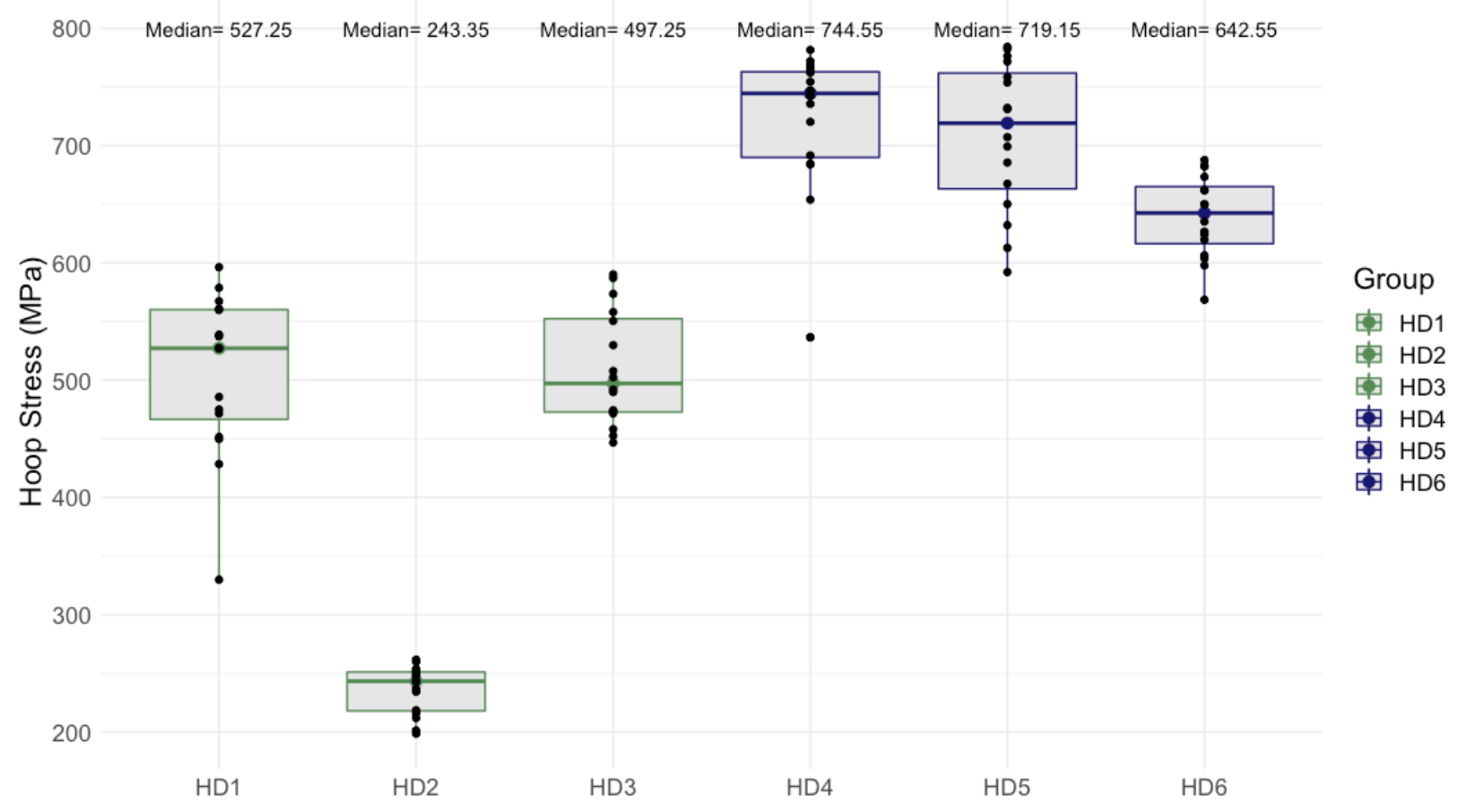

Figure 22. Boxplot of hoop stress measurements for all hole drilling measurements.

\section{Conclusion}

Cutting through the weld of a BTC container using a 4140 cutter resulted in a significant increase in the residual hoop stress near the outer weld. While the residual stresses in the container prior to cutting the weld are above that needed to enable stress corrosion crack growth, the lowered residual stress makes the uncut BTC less representative of containers in the field. It is therefore recommended that future test containers be cut through the weld using the 4140 cutter same method used for many BTCs currently in storage at SRS. 


\section{References}

1. Dunn, K. A.; Mickalonis, J. I., Residual Stresses in 3013 Containers. Journal of Nuclear Material Management 2010, 37 (2), 31-38.

2. Stroud, M. A.; Prime, M. B.; Veirs, D. K.; Berg, J. M.; Clausen, B.; Worl, L. A.; DeWald, A. Assessment of Residual Stresses in 3013 Inner and Outer Containers and Teardrop Samples; LA-UR-15-29376; Los Alamos National Laboratory: Los Alamos, NM, 2015.

3. Tung, D. H., J.E.; Rios, D; Narlesky, J.E.; Stroud, M.A.; Berg, J.M.; Worl, L.A. 3013 BTC Welding at Los Alamos; Los Alamos National Laboratory: Los Alamos, NM, 2018.

4. Dunn, K. A.; Louthan, M. R., Jr.; Rawls, G. B.; Sindelar, R. L.; Zapp, P. E.; McClard, J. W., Container materials, fabrication, and robustness. JNMM 2010, 38 (2), 17-24.

5. ASTM, Standard E837-08 "Standard Test Method for Determining Residual Stresses by the Hole-Drilling Strain-Gage Method". ASTM International: West Conshohocken, PA, 2008.

\section{Acknowledgements}

Funding for this work was provided to the MIS Program by the Assistant Manager for Nuclear Materials Stabilization, Savannah River Operations Office, Department of Energy's Office of Environmental Management. The authors would like to acknowledge James Fiscus, Joel Jones and Michael Brown from SRS for performing weld cuts and lid removal and Hill Engineering for conducting the hole drilling measurements. 


\section{Appendix A: Material properties in 3013 inner BTC flow formed containers}

\begin{tabular}{|c|c|c|c|c|c|c|}
\hline Sample & \multicolumn{2}{|c|}{$\begin{array}{c}\text { Tensile Strength } \\
\text { (MPa) }\end{array}$} & \multicolumn{2}{c|}{$\begin{array}{c}\text { Yield Strength } \\
(\mathrm{MPa})\end{array}$} & \multicolumn{2}{c|}{$\begin{array}{c}\text { Elongation } \\
\%\end{array}$} \\
\hline & Longitudinal & Traverse & Longitudinal & Traverse & Longitudinal & Traverse \\
\hline $\begin{array}{c}\text { SRS/Hanford/LANL } \\
\text { 3013 Inner Flow Formed }\end{array}$ & $1440-1490$ & $1520-1590$ & $1250-1450$ & $1300-1370$ & $4 \%$ & $4-5 \%$ \\
\hline
\end{tabular}

\section{Appendix B: Letter documenting BTC material properties}

\begin{abstract}
Westinghouse Savannah River Company MATERIALS TECHNOLOGY SECTION

Materials Consultation
\end{abstract}

September 17, 2001

TO: $\quad$ EES Job Folder 22769 Document Control, 730-A FROM: W. L. Daugherty, 730-A
Materials Technology Section

Tensile Properties of Typical Bagless Transfer Container (U)

Reference 1 requested material property data for a Bagless Transfer Container (BTC). This data was needed to compare the as-fabricated properties to those of the original bar stock. The following data was provided, and is documented herein for retention purposes.

Hardness data (originally reported in Reference 2), taken from BTC \#279:

\begin{tabular}{|l|l|l|}
\hline Location of Measurement & Microhardness Reading & Converted Rockwell Hardness \\
\hline Can wall "far" from weld & $440-470 \mathrm{HK}$ & $44-45 \mathrm{HRC}$ \\
\hline Can wall HAZ & $180-220 \mathrm{HK}$ & $84-94 \mathrm{HRB}$ \\
\hline Weld bead & $180-270 \mathrm{HK}$ & $85 \mathrm{HRB}-24 \mathrm{HRC}$ \\
\hline Plug HAZ & $230-260 \mathrm{HK}$ & $96 \mathrm{HRB}-23 \mathrm{HRC}$ \\
\hline Plug base metal & $181-210 \mathrm{HK}$ & $85-92 \mathrm{HRB}$ \\
\hline
\end{tabular}

Tensile data (originally reported in 723-A MetLab report 200105001), taken from remnant of BTC \#607:

\begin{tabular}{|l|l|l|l|l|}
\hline Specimen & Tensile Strength & Yield Strength & Elongation & Reduction of Area \\
\hline \#1 Longitudinal & $209 \mathrm{ksi}$ & $181 \mathrm{ksi}$ & $*$ & $28 \%$ \\
\hline \#2 Longitudinal & $216 \mathrm{ksi}$ & $210 \mathrm{ksi}$ & $4 \%$ & $28 \%$ \\
\hline \#1 Transverse & $230 \mathrm{ksi}$ & $189 \mathrm{ksi}$ & $5 \%$ & $4 \%$ \\
\hline \#2 Transverse & $220 \mathrm{ksi}$ & $198 \mathrm{ksi}$ & $4 \%$ & $11 \%$ \\
\hline
\end{tabular}

* Sample broke outside the gage area - no elongation data was obtained.

References

1. Electronic mail message from D. Boyce to W. Daugherty, "BTS Can Properties", 4/27/00.

2. G-TRT-A-00001, "Failure Analysis of FB-Line Failed Bagless Transfer Can", W. Daugherty, 1/19/00. 


\section{Appendix C: Residual Stress and Uncertainty Measurements*}

*Data at depths greater than $0.79 \mathrm{~mm}$ were not included in the statistical analysis due to increasing uncertainty in data at depths greater than half way through the $1.5 \mathrm{~mm}$ wall.

\begin{tabular}{|c|c|c|c|c|c|c|}
\hline & \multicolumn{3}{|c|}{ H5117_HD9 (OD) } & \multicolumn{3}{c|}{ H5117_HD10 (OD) } \\
\hline $\begin{array}{c}\text { Depth } \\
\text { (mm) }\end{array}$ & $\begin{array}{c}\text { Axial } \\
\text { (MPa) }\end{array}$ & $\begin{array}{c}\text { Hoop } \\
\text { (MPa) }\end{array}$ & $\begin{array}{c}\text { Uncertainty } \\
\text { (MPa) }\end{array}$ & $\begin{array}{c}\text { Axial } \\
\text { (MPa) }\end{array}$ & $\begin{array}{c}\text { Hoop } \\
\text { (MPa) }\end{array}$ & $\begin{array}{c}\text { Uncertainty } \\
\text { (MPa) }\end{array}$ \\
\hline \hline 0.013 & -140.3 & 10.0 & 23.4 & -250.3 & -62.7 & 10.3 \\
\hline 0.064 & -111.4 & 81.7 & 14.5 & -244.4 & -41.7 & 4.1 \\
\hline 0.127 & -148.2 & 124.8 & 19.3 & -239.3 & -20.0 & 6.9 \\
\hline 0.178 & -197.9 & 167.5 & 17.9 & -233.1 & 1.4 & 6.9 \\
\hline 0.229 & -218.9 & 204.4 & 17.9 & -227.9 & 23.1 & 6.2 \\
\hline 0.279 & -191.7 & 245.5 & 17.9 & -221.3 & 44.8 & 6.2 \\
\hline 0.330 & -167.9 & 295.5 & 17.9 & -215.5 & 65.8 & 6.2 \\
\hline 0.381 & -156.2 & 347.2 & 18.6 & -209.6 & 86.9 & 6.2 \\
\hline 0.432 & -155.5 & 411.3 & 19.3 & -202.7 & 107.6 & 6.9 \\
\hline 0.483 & -158.6 & 459.2 & 20.0 & -195.1 & 127.6 & 6.9 \\
\hline 0.533 & -159.6 & 481.6 & 20.7 & -187.2 & 146.5 & 6.9 \\
\hline 0.584 & -154.4 & 484.0 & 21.4 & -178.9 & 165.8 & 6.9 \\
\hline 0.635 & -158.9 & 476.8 & 22.8 & -169.6 & 183.4 & 7.6 \\
\hline 0.686 & -188.2 & 488.9 & 23.4 & -160.0 & 201.3 & 7.6 \\
\hline 0.737 & -236.5 & 542.6 & 26.2 & -150.0 & 218.2 & 8.3 \\
\hline 0.787 & -265.8 & 608.5 & 29.6 & -140.0 & 235.1 & 9.0 \\
\hline 0.838 & -253.4 & 643.0 & 30.3 & -128.9 & 251.7 & 9.0 \\
\hline 0.889 & -218.9 & 643.0 & 37.9 & -118.6 & 268.9 & 10.3 \\
\hline 0.940 & -186.2 & 639.9 & 69.0 & -107.9 & 285.1 & 17.2 \\
\hline 0.991 & -160.3 & 643.6 & 113.8 & -96.9 & 301.7 & 28.3 \\
\hline & & & & & & \\
\hline
\end{tabular}

Table C1.a. Stresses and uncertainties in SRS-Welded container H5117. 
Appendix C (continued)

\begin{tabular}{|c|c|c|c|c|c|c|}
\hline & \multicolumn{3}{|c|}{ H5117_HD11 (ID) } & \multicolumn{3}{c|}{ H5117_HD12 (ID) } \\
\hline $\begin{array}{c}\text { Depth } \\
\text { (mm) }\end{array}$ & $\begin{array}{c}\text { Axial } \\
\text { (MPa) }\end{array}$ & $\begin{array}{c}\text { Hoop } \\
\text { (MPa) }\end{array}$ & $\begin{array}{c}\text { Uncertainty } \\
\text { (MPa) }\end{array}$ & $\begin{array}{c}\text { Axial } \\
\text { (MPa) }\end{array}$ & $\begin{array}{c}\text { Hoop } \\
\text { (MPa) }\end{array}$ & $\begin{array}{c}\text { Uncertainty } \\
\text { (MPa) }\end{array}$ \\
\hline \hline 0.013 & 162.7 & 670.2 & 17.2 & 163.4 & 713.6 & 17.2 \\
\hline 0.064 & 225.8 & 736.0 & 8.3 & 210.6 & 802.2 & 7.6 \\
\hline 0.127 & 271.3 & 785.7 & 13.1 & 266.1 & 907.4 & 12.4 \\
\hline 0.178 & 295.8 & 814.3 & 13.1 & 330.3 & 1026.7 & 12.4 \\
\hline 0.229 & 306.8 & 828.1 & 11.7 & 382.7 & 1114.9 & 11.7 \\
\hline 0.279 & 304.4 & 828.4 & 12.4 & 397.5 & 1135.3 & 11.7 \\
\hline 0.330 & 299.6 & 827.7 & 12.4 & 379.6 & 1110.4 & 11.7 \\
\hline 0.381 & 302.3 & 834.6 & 12.4 & 349.6 & 1074.9 & 12.4 \\
\hline 0.432 & 297.9 & 835.7 & 13.1 & 319.6 & 1042.2 & 12.4 \\
\hline 0.483 & 269.6 & 815.7 & 13.8 & 288.6 & 1009.8 & 13.1 \\
\hline 0.533 & 217.9 & 772.2 & 14.5 & 254.4 & 972.9 & 13.8 \\
\hline 0.584 & 169.6 & 735.0 & 15.2 & 213.7 & 921.2 & 14.5 \\
\hline 0.635 & 135.1 & 712.9 & 15.9 & 162.0 & 857.0 & 15.2 \\
\hline 0.686 & 108.9 & 700.5 & 17.2 & 99.3 & 791.5 & 16.5 \\
\hline 0.737 & 83.8 & 689.2 & 19.3 & 28.6 & 736.0 & 18.6 \\
\hline 0.787 & 44.8 & 666.7 & 20.0 & -46.2 & 687.4 & 19.3 \\
\hline 0.838 & -18.3 & 618.8 & 21.4 & -123.8 & 644.3 & 21.4 \\
\hline 0.889 & -110.3 & 543.3 & 32.4 & -203.1 & 598.1 & 32.4 \\
\hline 0.940 & -218.9 & 451.3 & 55.2 & -283.4 & 545.4 & 53.8 \\
\hline 0.991 & -334.8 & 352.0 & 83.4 & -365.8 & 490.6 & 80.0 \\
\hline
\end{tabular}

Table C1.b. Stresses and uncertainties in SRS-Welded container H5117. 
Appendix C (continued)

\begin{tabular}{|c|c|c|c|}
\hline \multicolumn{4}{|c|}{ LANL-Welded H8411 Hoop direction stress } \\
\hline $\begin{array}{c}\text { Depth } \\
(\mathrm{mm})\end{array}$ & $\begin{array}{c}\text { H8411-HD9 (OD) } \\
\text { Stress (MPa) }\end{array}$ & $\begin{array}{c}\text { H8411-HD11 (ID) } \\
\text { Stress (MPa) }\end{array}$ & $\begin{array}{c}\text { H8411-HD12 standard res (ID) } \\
\text { Stress (MPa) }\end{array}$ \\
\hline \hline 0.0254 & -135.6 & -192.4 & -228.2 \\
\hline 0.0762 & -12.7 & 20.0 & 219.3 \\
\hline 0.127 & 72.7 & 195.1 & 493.7 \\
\hline 0.1778 & 115.0 & 305.4 & 571.6 \\
\hline 0.2286 & 130.9 & 362.0 & 548.2 \\
\hline 0.2794 & 147.6 & 388.9 & 504.0 \\
\hline 0.3302 & 168.6 & 403.4 & 477.8 \\
\hline 0.381 & 191.9 & 393.7 & 468.2 \\
\hline 0.4318 & 208.5 & 371.6 & 457.8 \\
\hline 0.4826 & 216.9 & 359.2 & 451.6 \\
\hline 0.5334 & 215.8 & 356.5 & 447.5 \\
\hline 0.5842 & 220.0 & 354.4 & 437.1 \\
\hline 0.635 & 230.8 & 336.5 & 403.4 \\
\hline 0.6858 & 237.3 & 299.2 & 358.5 \\
\hline 0.7366 & 224.5 & 245.5 & 304.1 \\
\hline 0.7874 & 183.7 & 182.7 & 248.9 \\
\hline 0.8382 & 119.0 & 122.7 & 206.2 \\
\hline 0.889 & 32.5 & 73.1 & 178.6 \\
\hline 0.9398 & -69.5 & 31.7 & 162.7 \\
\hline 0.9906 & -175.2 & -7.6 & 151.0 \\
\hline
\end{tabular}

Table C2.a. Stresses for LANL-Welded container H8411. 
Appendix C (continued)

\begin{tabular}{|c|c|c|c|}
\hline \multicolumn{4}{|c|}{ LANL-welded H8411 Axial direction stress } \\
\hline $\begin{array}{c}\text { Depth } \\
(\mathrm{mm})\end{array}$ & $\begin{array}{c}\text { H8411-HD9 } \\
\text { Stress (MPa) }\end{array}$ & $\begin{array}{c}\text { H8411-HD11 } \\
\text { Stress (MPa) }\end{array}$ & $\begin{array}{c}\text { H8411-HD12 standard res } \\
\text { Stress (MPa) }\end{array}$ \\
\hline \hline 0.0254 & -399.5 & -195.1 & -270.3 \\
\hline 0.0762 & -323.9 & 5.5 & 106.2 \\
\hline 0.127 & -274.5 & 188.2 & 328.2 \\
\hline 0.1778 & -255.9 & 317.2 & 379.2 \\
\hline 0.2286 & -264.6 & 377.2 & 341.3 \\
\hline 0.2794 & -274.3 & 387.5 & 282.0 \\
\hline 0.3302 & -267.9 & 376.5 & 241.3 \\
\hline 0.381 & -251.3 & 345.4 & 216.5 \\
\hline 0.4318 & -236.1 & 306.1 & 188.9 \\
\hline 0.4826 & -219.8 & 276.5 & 155.1 \\
\hline 0.5334 & -201.9 & 253.7 & 113.1 \\
\hline 0.5842 & -184.9 & 222.0 & 62.1 \\
\hline 0.635 & -172.6 & 171.7 & -4.1 \\
\hline 0.6858 & -166.3 & 100.7 & -70.3 \\
\hline 0.7366 & -171.9 & 24.1 & -128.9 \\
\hline 0.7874 & -204.0 & -48.3 & -176.5 \\
\hline 0.8382 & -273.4 & -115.1 & -209.6 \\
\hline 0.889 & -378.8 & -180.6 & -230.3 \\
\hline 0.9398 & -506.5 & -245.5 & -244.8 \\
\hline 0.9906 & -641.7 & -308.9 & -257.9 \\
\hline
\end{tabular}

Table C2.b. Stresses for LANL-Welded container H8411. 
Appendix C (continued)

\begin{tabular}{|c|c|c|c|}
\hline \multicolumn{4}{|c|}{ LANL-Welded H8411 Axial/Hoop uncertainties } \\
\hline $\begin{array}{c}\text { Depth } \\
(\mathrm{mm})\end{array}$ & $\begin{array}{c}\text { H8411-HD9 (OD) } \\
\text { Uncertainties (MPa) }\end{array}$ & $\begin{array}{c}\text { H8411-HD11 (ID) } \\
\text { Uncertainties (MPa) }\end{array}$ & $\begin{array}{c}\text { H8411-HD12 (ID) standard res } \\
\text { Uncertainties (MPa) }\end{array}$ \\
\hline \hline 0.0254 & 26.4 & 24.1 & 29.0 \\
\hline 0.0762 & 16.7 & 11.0 & 20.0 \\
\hline 0.127 & 22.0 & 17.9 & 24.8 \\
\hline 0.1778 & 20.1 & 17.2 & 22.8 \\
\hline 0.2286 & 20.0 & 15.9 & 22.8 \\
\hline 0.2794 & 20.3 & 16.5 & 23.4 \\
\hline 0.3302 & 20.5 & 16.5 & 23.4 \\
\hline 0.381 & 20.9 & 16.5 & 24.1 \\
\hline 0.4318 & 21.5 & 17.2 & 24.8 \\
\hline 0.4826 & 22.2 & 17.9 & 25.5 \\
\hline 0.5334 & 23.0 & 18.6 & 26.2 \\
\hline 0.5842 & 24.1 & 18.6 & 27.6 \\
\hline 0.635 & 25.3 & 20.0 & 29.0 \\
\hline 0.6858 & 26.4 & 21.4 & 29.6 \\
\hline 0.7366 & 28.9 & 23.4 & 32.4 \\
\hline 0.7874 & 32.7 & 24.1 & 36.5 \\
\hline 0.8382 & 33.7 & 26.9 & 38.6 \\
\hline 0.889 & 40.4 & 37.2 & 42.7 \\
\hline 0.9398 & 73.4 & 61.4 & 77.9 \\
\hline 0.9906 & 124.3 & 94.5 & 136.5 \\
\hline
\end{tabular}

Table C2.c. Stress uncertainties for LANL-Welded container H8411. 
Appendix C (continued)

\begin{tabular}{|c|c|c|c|c|c|c|c|}
\hline \multicolumn{7}{|c|}{ LANL-welded container H6291 Hoop direction stress } \\
\hline \multirow{2}{*}{ Depth } & & & & & $\begin{array}{c}\text { HD7 } \\
\text { (16 mm below } \\
\text { weld toe }\end{array}$ \\
& HD1 & HD2 & HD3 & HD4 & HD5 & HD6 & Stress \\
\cline { 2 - 9 } & Stress & Stress & Stress & Stress & Stress & Stress & (MPa) \\
\hline \hline$(\mathrm{mm})$ & (MPa) & (MPa) & (MPa) & (MPa) & (MPa) & $(\mathrm{MPa})$ & 865.3 \\
\hline 0.03 & 329.9 & 234.4 & 471.6 & 536.6 & 592.2 & 650.2 & 691.6 \\
\hline 0.08 & 428.5 & 212.0 & 489.9 & 653.9 & 612.8 & 626.7 & 535.4 \\
\hline 0.13 & 475.0 & 198.6 & 473.3 & 684.0 & 632.2 & 606.5 & 420.3 \\
\hline 0.18 & 471.6 & 201.3 & 452.6 & 684.7 & 650.2 & 597.9 & 359.2 \\
\hline 0.23 & 449.9 & 216.2 & 446.8 & 691.7 & 667.5 & 603.8 & 330.3 \\
\hline 0.28 & 451.6 & 236.8 & 458.2 & 720.3 & 685.6 & 619.7 & 285.8 \\
\hline 0.33 & 485.7 & 253.0 & 474.4 & 735.6 & 707.2 & 635.3 & 202.4 \\
\hline 0.38 & 527.4 & 253.7 & 491.9 & 747.1 & 731.1 & 649.8 & 77.6 \\
\hline 0.43 & 559.9 & 248.6 & 507.8 & 772.1 & 753.8 & 662.3 & -53.8 \\
\hline 0.48 & 560.9 & 243.0 & 529.9 & 781.6 & 771.7 & 673.4 & -150.7 \\
\hline 0.53 & 538.8 & 243.7 & 550.5 & 768.4 & 782.4 & 683.0 & -222.4 \\
\hline 0.58 & 527.1 & 250.6 & 573.6 & 765.4 & 784.3 & 687.7 & -288.9 \\
\hline 0.64 & 537.4 & 259.9 & 590.2 & 762.2 & 776.4 & 682.1 & -345.4 \\
\hline 0.69 & 567.4 & 261.7 & 587.1 & 754.5 & 758.6 & 661.8 & -389.6 \\
\hline 0.74 & 596.4 & 249.2 & 558.1 & 747.0 & 732.2 & 624.3 & -428.5 \\
\hline 0.79 & 578.8 & 218.6 & 502.6 & 742.1 & 699.2 & 568.6 & -468.9 \\
\hline 0.84 & 489.2 & 169.3 & 422.3 & 730.0 & 661.9 & 497.0 & -515.1 \\
\hline 0.89 & 354.7 & 107.6 & 326.5 & 691.7 & 622.1 & 413.9 & -567.1 \\
\hline 0.94 & 200.6 & 38.3 & 225.5 & 630.5 & 581.4 & 325.1 & -621.6 \\
\hline 0.99 & 41.0 & -32.1 & 121.0 & 563.0 & 540.6 & 234.5 & \\
\hline
\end{tabular}

Table C3.a. Hoop and Axial Stresses in LANL-welded container H6291 measured from the OD. 
Appendix C (continued)

\begin{tabular}{|c|c|c|c|c|c|c|}
\hline \multicolumn{7}{|c|}{ LANL-welded container H6291 Axial direction stress } \\
\hline \multirow{2}{*}{ Depth } & HD1 & HD2 & HD3 & HD4 & HD5 & HD6 \\
\cline { 2 - 7 } & Stress & Stress & Stress & Stress & Stress & Stress \\
\hline \hline$(\mathrm{mm})$ & (MPa) & (MPa) & (MPa) & (MPa) & $(\mathrm{MPa})$ & $(\mathrm{MPa})$ \\
\hline \hline 0.03 & -512.6 & -518.5 & -608.1 & -391.4 & -332.2 & -355.6 \\
\hline 0.08 & -426.4 & -476.1 & -544.3 & -291.9 & -310.9 & -361.8 \\
\hline 0.13 & -381.3 & -431.6 & -512.6 & -267.2 & -290.8 & -364.8 \\
\hline 0.18 & -362.7 & -386.1 & -485.0 & -255.3 & -272.2 & -356.4 \\
\hline 0.23 & -349.9 & -340.9 & -449.5 & -235.6 & -254.4 & -333.9 \\
\hline 0.28 & -320.6 & -298.2 & -402.3 & -202.5 & -235.9 & -302.0 \\
\hline 0.33 & -272.7 & -262.7 & -364.0 & -185.0 & -213.9 & -271.1 \\
\hline 0.38 & -225.5 & -235.8 & -334.1 & -170.3 & -189.8 & -242.1 \\
\hline 0.43 & -176.5 & -212.0 & -304.4 & -144.8 & -167.0 & -215.9 \\
\hline 0.48 & -142.4 & -187.2 & -267.2 & -133.1 & -149.1 & -192.1 \\
\hline 0.53 & -125.8 & -158.9 & -232.7 & -141.3 & -138.5 & -170.8 \\
\hline 0.58 & -111.4 & -130.0 & -205.5 & -139.2 & -136.8 & -155.2 \\
\hline 0.64 & -102.4 & -104.1 & -193.1 & -137.1 & -145.1 & -150.9 \\
\hline 0.69 & -91.7 & -91.4 & -201.7 & -143.0 & -163.2 & -162.0 \\
\hline 0.74 & -84.8 & -96.9 & -230.6 & -159.0 & -190.2 & -190.8 \\
\hline 0.79 & -112.0 & -120.7 & -279.2 & -184.8 & -223.6 & -238.1 \\
\hline 0.84 & -187.9 & -161.7 & -341.6 & -226.1 & -261.6 & -301.5 \\
\hline 0.89 & -297.5 & -216.5 & -414.0 & -298.5 & -301.9 & -376.5 \\
\hline 0.94 & -421.3 & -277.5 & -493.0 & -395.2 & -343.2 & -457.2 \\
\hline 0.99 & -550.5 & -340.9 & -575.4 & -499.9 & -384.7 & -539.7 \\
\hline
\end{tabular}

Table C3.b. Hoop and Axial Stresses in LANL-welded container H6291 measured from the OD. 
Appendix C (continued)

\begin{tabular}{|c|c|c|c|c|c|c|}
\hline \multicolumn{7}{|c|}{ LANL-welded container H6291 Uncertainties } \\
\hline \multirow{2}{*}{ Depth } & HD1 & HD2 & HD3 & HD4 & HD5 & HD6 \\
\cline { 2 - 7 } & Axial/Hoop & Axial/Hoop & Axial/Hoop & Axial/Hoop & Axial/Hoop & Axial/Hoop \\
\hline$(\mathrm{mm})$ & $(\mathrm{MPa})$ & $(\mathrm{MPa})$ & $(\mathrm{MPa})$ & $(\mathrm{MPa})$ & $(\mathrm{MPa})$ & $(\mathrm{MPa})$ \\
\hline \hline 0.025 & 22.8 & 16.5 & 22.8 & 27.2 & 11.4 & 16.3 \\
\hline 0.076 & 15.2 & 6.2 & 14.5 & 20.7 & 5.1 & 6.7 \\
\hline 0.127 & 19.3 & 9.7 & 19.3 & 23.8 & 4.7 & 10.0 \\
\hline 0.178 & 17.2 & 11.7 & 17.2 & 22.2 & 6.9 & 11.4 \\
\hline 0.229 & 17.9 & 10.3 & 17.2 & 22.3 & 7.5 & 10.7 \\
\hline 0.279 & 17.9 & 10.3 & 17.9 & 22.5 & 7.1 & 10.3 \\
\hline 0.330 & 17.9 & 10.3 & 17.9 & 22.9 & 6.8 & 10.4 \\
\hline 0.381 & 18.6 & 11.0 & 18.6 & 23.3 & 6.8 & 10.7 \\
\hline 0.432 & 19.3 & 11.0 & 18.6 & 24.0 & 7.0 & 10.9 \\
\hline 0.483 & 20.0 & 11.7 & 19.3 & 24.8 & 7.3 & 11.2 \\
\hline 0.533 & 20.7 & 11.7 & 20.0 & 25.6 & 7.8 & 11.5 \\
\hline 0.584 & 21.4 & 12.4 & 21.4 & 26.8 & 8.3 & 12.2 \\
\hline 0.635 & 22.8 & 13.1 & 22.8 & 28.1 & 8.7 & 13.2 \\
\hline 0.686 & 24.1 & 14.5 & 23.4 & 29.4 & 9.1 & 14.0 \\
\hline 0.737 & 26.2 & 15.9 & 26.2 & 31.2 & 9.8 & 14.5 \\
\hline 0.787 & 29.6 & 15.9 & 29.6 & 35.6 & 11.9 & 15.8 \\
\hline 0.838 & 31.0 & 20.0 & 30.3 & 38.4 & 16.3 & 20.1 \\
\hline 0.889 & 37.9 & 31.0 & 37.9 & 41.3 & 23.1 & 28.9 \\
\hline 0.940 & 68.9 & 47.6 & 68.3 & 74.2 & 31.6 & 42.9 \\
\hline 0.991 & 115.1 & 67.6 & 113.8 & 134.2 & 41.2 & 60.9 \\
\hline
\end{tabular}

Table C3.c. Hoop and Axial Stresses uncertainties in LANL-welded container H6291 measured from the OD. 


\section{Appendix D: Cutter Wheel Drawings}

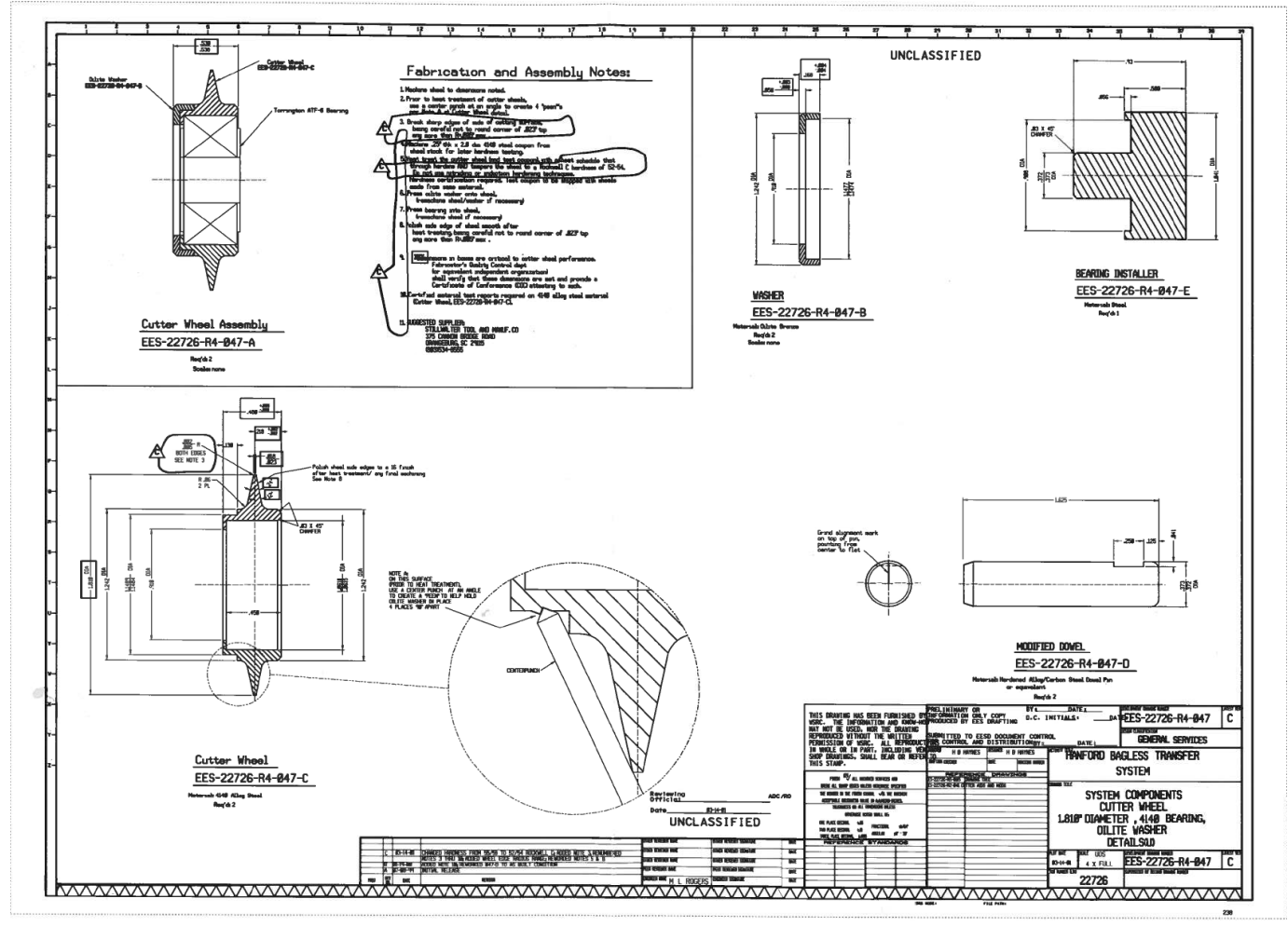

Figure D1. Drawing for the 4140 cutter wheel.

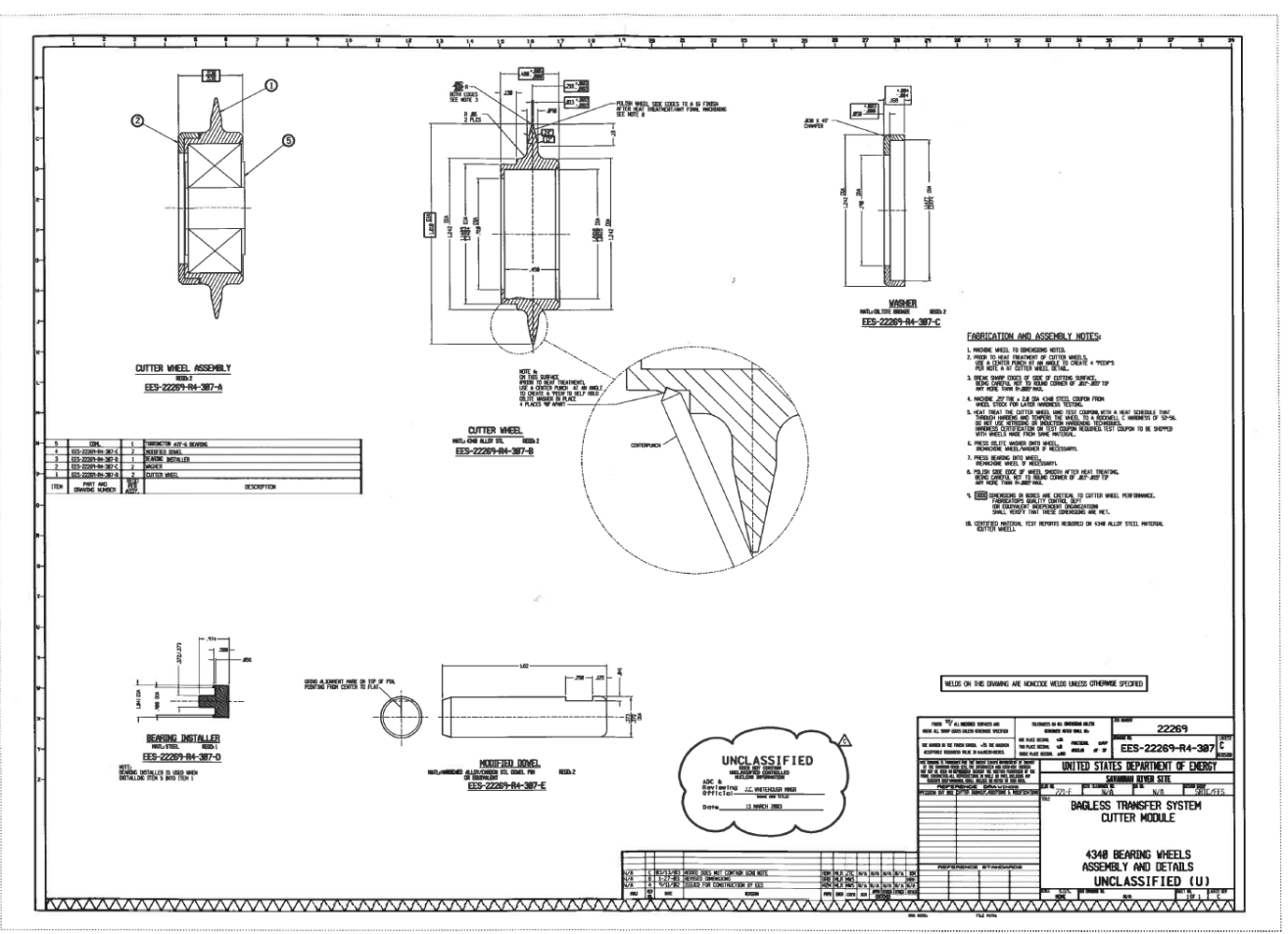

Figure D2. Drawing for the 4340 cutter wheel. 